\title{
CONSTITUTIONAL RIGHTS IN HONG KONG'S COURT OF FINAL APPEAL
}

\author{
Simon NM Young*
}

\section{TABLE OF CONTENTS}

I. Introduction

II. Tracking the Development
A. Caseload and Trends
B. Areas of Law and Rights Considered
C. Who Are the Litigants in Constitutional Rights Cases?
D. Legal Representation
E. Interveners and Amicus
F. Nature of the Constitutional Arguments
G. Diversity of Judicial Opinions
H. Citation of Authorities
I. Time to Hear
J. Time to Render Judgment
K. Length of Judgments

III. Impact for Litigants and Others
A. Government's Win/Loss Record
B. Overturning the Court Below
C. How Are Constitutional Rights Used?
D. Types of Relief Ordered
E. Impact of Jurisprudence beyond the Litigants

IV. Conclusions
A. Character of Rights Litigation in the CFA
B. International Influence
C. Decision-Making: Consensus-Driven, Efficient and Consistent
D. Impact of the Jurisprudence
E. The Future

Annex: First Ten Years of Rights Cases in the CFA

\section{INTRODUCTION}

Following the abolition of appeals to the Judicial Committee of the Privy Council (PC), Hong Kong established its Court of Final Appeal (CFA) on July

\footnotetext{
* Associate Professor and Director, Centre for Comparative and Public Law, Faculty of Law, University of Hong Kong. The work described in this article was fully supported by a grant from the Research Grants Council of the Hong Kong Special Administrative Region, China (Project No. HKU 7467/06H). I thank my team members, Kate Egan, Antonio Da Roza, Ernest Ng and Bryan Chan, for their helpful research assistance, and P.Y. Lo and Michael Thomas for their comments on an earlier draft. The data for this study was obtained from the Hong Kong judiciary website: www. judiciary.gov.hk. An earlier version of this article was delivered at the Second Conference on Law and Citizenship sponsored by the Legislative Assembly of the Macau SAR, October 20-22, 2008.
} 
1, 1997 under a new constitutional order. As the apex court in Hong Kong, the CFA sits in panels of five judges to hear final appeals from the High Court, which consists of a Court of Appeal and Court of First Instance. Below the High Court are two levels of trial courts, known as the District Court and Magistrates' Courts, several specialized tribunals, and a coroner's court. ${ }^{1}$ The new constitutional order defined by the Basic Law did not contemplate further appeals from the CFA to any court in mainland China. ${ }^{2}$ The CFA was given the power of final adjudication, but the power of final interpretation of the Basic Law was reserved for the Standing Committee of the National People's Congress (NPCSC) in Beijing. ${ }^{3}$

The CFA considered its first constitutional rights case in January 1999, more than 18 months after its establishment. Chief Justice Andrew Li's unanimous judgment in $\mathrm{Ng} \mathrm{Ka}$ Ling $\mathrm{v}$. Director of Immigration declared the judiciary's robust approach to constitutional review on an issue of great societal importance permanent residency in Hong Kong. ${ }^{4}$ Chief Justice Li declared in no uncertain terms the judiciary's power and duty to declare laws and executive acts invalid if found to be inconsistent with the Basic Law; in discharging this duty, courts served "as a constitutional check on the executive and legislative branches of government to ensure that they act in accordance with the Basic Law. ${ }^{\prime 5} \mathrm{Ng} \mathrm{Ka}$ Ling, however, also brought about the first constitutional crisis in Hong Kong after the NPCSC acceded to the Hong Kong government's request to replace the CFA's interpretation of the Basic Law with a narrower one. But the CFA's robust approach to rights was uninhibited by this early controversy and over the next ten years it decided 44 more rights cases in many different areas beyond the right of abode.

This article examines the first decade of constitutional rights cases in the CFA. ${ }^{6}$ It considers how the jurisprudence in this area has developed and what impact it has had for litigants and others. Existing literature provides conventional doctrinal analysis of the judgments. ${ }^{7}$ This study is unique as it generates

${ }^{1}$ For more information on the Hong Kong court system, see Hong Kong Judiciary, http:/ / www. judiciary.gov.hk/en/index/index.htm (last visited Mar. 11, 2011).

2 See Xianggan Jiben Fa [The Basic Law of the Hong Kong Special Administrative Region of the People's Republic of China] [hereinafter Basic Law].

3 Id. arts. 82 \& 158. Hong Kong courts may still interpret the Basic Law in adjudicating cases, but if in reaching a final decision it is necessary to interpret the provisions of the Basic Law concerning affairs which are the responsibility of the Central People's Government, or concerning the relationship between the Central Authorities and the Region a binding interpretation must be obtained from the NPCSC, via the CFA (see Art. 158).

${ }_{4} \mathrm{Ng}$ Ka Ling \& Others v. Dir. of Immigration, 2 H.K.C.F.A.R. 4 (1999). Much has been written about this case and its aftermath. See generally Hong Kong's Constitutional Debate: Conflict over Interpretation (Yash Ghai, Hualing Fu \& Johannes Chan eds., 2000); Anne R. Fokstuen, "The 'Right of Abode' Cases: Hong Kong's Constitutional Crisis", 26 Hastings Int'l E Comp. L. Rev. 265 (2003).

${ }^{5} \mathrm{Ng}$ Ka Ling, 2 H.K.C.F.A.R. at 25.

${ }^{6}$ The criterion for selecting cases for this study was whether the full Court considered, as obiter or ratio, the meaning or effect of a fundamental right in the Basic Law or Hong Kong Bill of Rights. Thus, some cases which fell outside of this criterion, even though their subject matter concerned human rights, were not included. A list of the cases can be found in the Annex to this article arranged according to the date of the decision. The ten-year period begins from the first decision decided on January 29, 1999.

7 See, e.g., Albert Chen, "Constitutional Adjudication in Post-1997 Hong Kong", 15 Pac. Rim L. \& Pol'y J. 627 (2006); The various articles in the 2007 Special Anniversary Issue of the Hong Kong Law Journal entitled "10 Years of the Basic Law" in volume 37, part 2, and particularly the 
quantitative data from the jurisprudence of the CFA and PC to present a comprehensive and statistical picture of the Court's performance and operation. The study discusses and explains the data by reference to the broader legal and social context in which the Court functions. It provides a quantitative basis from which to confirm or refute assumptions about the Court's human rights case law and impact. For example, there are some who believe that the Court has become too activist, but the overall data does not bear this out. ${ }^{8}$ It also provides new insights into the foundational years of the Court and serves as an essential starting point for future studies.

\section{TRACKING THE DEVELOPMENT}

\section{A. Caseload and Trends}

From January 1999 to January 2009, the CFA decided 45 constitutional rights cases. ${ }^{9}$ This represented about $17 \%$ of all decided cases in the CFA in the same period. ${ }^{10}$ There was no clear trend in the number of cases decided each year. The numbers fluctuated, ranging as high as seven and eight cases in the years 2003 and 2006 respectively (representing 33\% and 20\% of the total number of decided cases in those respective years) to as low as two cases in the years 2000 and 2004 (representing 6.3\% and $7.7 \%$ of the total number of decided cases in those respective years). ${ }^{11}$

It is difficult to compare this data with pre-1997 Hong Kong appeals to the PC. It was only in 1991 that Hong Kong was given a bill of rights and the first Hong Kong Bill of Rights (HKBOR) appeal in London was argued in March 1993. In total, the PC decided five HKBOR cases which included the often-cited Attorney General of Hong Kong v. Lee Kwong Kut concerned with justifying derogations from the presumption of innocence. ${ }^{12}$ This number represented only $7.0 \%$ of the total number of decided cases in the PC after the commencement date of the HKBOR in June $1991 .{ }^{13}$ This low figure reflected the generally fewer

articles by Johannes Chan and Po Jen Yap; K. Bokhary, "The First Decade of the Basic Law: A Judicial Perspective", H.K. Law.. Dec. 2007, available at http://www.hk-lawyer.com/InnerPages_ features/0/2761/2007/12 (last visited Mar. 18, 2011).

8 See, e.g., Dong Likun, "Power to Review Legislation of the Hong Kong Special Administrative Region Inconsistent with the Basic Law", 32 Chinese J. L. 3 (2010).

9 See infra Annex. An important decision of the CFA Appeal Committee (not the full Court) on the constitutionality of Rule 7 proceedings (which allow the CFA to dismiss leave applications without a hearing) was not included in this study. See Chow Shun Yung v. Wei Pih Stella, 6 H.K.C.F.A.R. 299 (2003).

${ }^{10}$ There were 265 decisions in substantive appeals in the CFA from 29 January 1999 to 28 January 2009. Forty-five of these cases were constitutional rights cases. In this study, the main decision in $\mathrm{Ng}$ Siu Tung \& Others v. Dir. of Immigration, 5 H.K.C.F.A.R. 1 (2002), together with the many consequential judgments, is counted as one decision.

11 See infra Annex.

12 See Att'y Gen. of H.K. v. Lee Kwong Kut [1993] A.C. 951 (P.C.); Ming Pao Newspapers Ltd. v. Att'y Gen. of H.K. [1996] 2 H.K.L.R. 239 (P.C.); Att'y Gen. of H.K. v. Charles Cheung Wai-Bun [1993] 1 H.K.C.L.R. 249 (P.C.); The Queen v. Chan Chi-Hung [1995] 2 H.K.C.L.R. 50 (P.C.); Fok Lai Ying v Governor in Council [1997] H.K.L.R.D. 810 (P.C.).

13 There were 71 Privy Council decisions in substantive appeals from June 1991 to July 1997. The Hong Kong Bill of Rights Ordinance (Cap. 383) had a savings clause (see s. 14) that delayed the operation of the HKBOR for one year in respect of several important statutes. Counting from the delayed date of operation, the five HKBOR cases represented $7.8 \%$ of the total number of decisions (64 decisions) in the relevant period. 
number of appeals from Hong Kong heard in the PC, due to the many barriers of accessing that court. ${ }^{14}$ When comparing the last decade of PC appeals with the first decade of CFA appeals, the PC decided only $44 \%$ of the total number of cases decided by the CFA (108 versus 244 decisions).

\section{B. Areas of Law and Rights Considered}

The CFA has its own case numbering system that divides all substantive appeals into criminal appeals, with the file designation FACC, and non-criminal appeals, with the file designation FACV. Of the 45 rights cases, 20 were FACC cases and 25 were FACV. Table 1 shows a further breakdown of these cases into different areas of law. ${ }^{15}$

\section{Table 1: CFA Rights Cases by Area of Law}

\begin{tabular}{|c|c|}
\hline Area of Law & Number of Cases \\
\hline Criminal Law & $22^{16}$ \\
\hline $\begin{array}{r}\text { Substantive Criminal Law } \\
\text { Case \#: } 6,15,16,31,35,41,42\end{array}$ & 7 \\
\hline $\begin{array}{c}\text { Criminal Procedure } \\
\text { Case \#: } 9,22,30,34,37,38,39,40,43\end{array}$ & 9 \\
\hline $\begin{array}{l}\text { Criminal Evidence } \\
\text { Case \#: } 23\end{array}$ & 1 \\
\hline $\begin{array}{l}\text { Sentencing (incl. binding over) } \\
\text { Case \#: } 3,18,24,26\end{array}$ & 4 \\
\hline Case \#: 4 & 1 \\
\hline Administrative Law & 17 \\
\hline $\begin{array}{c}\text { Immigration and Travel } \\
\text { Case \#: } 1,2,5,10,11,12,14,17,20,27\end{array}$ & 10 \\
\hline $\begin{array}{r}\text { Disciplinary } \\
\text { Case \#: } 25,32,33,45\end{array}$ & 4 \\
\hline $\begin{array}{l}\text { Land Reclamation } \\
\text { Case \#: } 19\end{array}$ & 1 \\
\hline $\begin{array}{l}\text { Regulatory/Public Welfare } \\
\text { Case \#: 29, } 44\end{array}$ & 2 \\
\hline $\begin{array}{l}\text { Anti-discrimination Law } \\
\text { Case \#: } 13\end{array}$ & 1 \\
\hline $\begin{array}{l}\text { Arbitration } \\
\text { Case \#: } 21\end{array}$ & 1 \\
\hline $\begin{array}{l}\text { Bankruptcy } \\
\text { Case \#: } 36\end{array}$ & 1 \\
\hline $\begin{array}{l}\text { Civil Procedure } \\
\text { Case \#: } 28\end{array}$ & 1 \\
\hline
\end{tabular}

\footnotetext{
14 See Simon NM Young \& Antonio Da Roza, "Judges and Judging in the Court of Final Appeal: A Statistical Picture", H.K. Law., Aug. 2010, available at http:/ /www.hk-lawyer.com/InnerPages_ features /0/3237/2010/8 (last visited Mar. 18, 2011).

${ }^{15}$ Note that the Case \# in the table refers to the Case \# column in the Annex.

${ }^{16}$ This figure also includes two FACV appeals concerned with judicial review challenges to covert surveillance used for criminal investigations and the detention of transferred prisoners.
} 


\begin{tabular}{|l|c|}
\hline \multicolumn{1}{|c|}{ Area of Law } & Number of Cases \\
\hline $\begin{array}{l}\text { Defamation } \\
\text { Case \#: } 7\end{array}$ & 1 \\
\hline $\begin{array}{l}\text { Election Law } \\
\text { Case \#: } 8\end{array}$ & 1 \\
\hline
\end{tabular}

All but four cases arose in a public law context and almost half are in the criminal law context. A quarter of the cases were in the immigration and travel context, many being right of abode cases, decided in the period 1999 to 2004 .

The cases can also be classified by the constitutional right or freedom considered by the court. Table 2 shows the various Basic Law and HKBOR provisions which have been considered by the CFA. Some cases are counted more than once if more than one right was considered in a particular case.

Table 2: Rights and Freedoms Considered by the CFA

\begin{tabular}{|l|c|c|c|}
\hline \multicolumn{1}{|c|}{ Right or Freedom } & $\begin{array}{c}\text { Basic Law } \\
\text { Provision }\end{array}$ & $\begin{array}{c}\text { HKBOR } \\
\text { Provision }\end{array}$ & $\begin{array}{c}\text { Number of } \\
\text { Decisions }\end{array}$ \\
\hline Right of abode & 24 & & $\mathbf{8}$ \\
\hline Equality and non-discrimination & 25 & 22 & $\mathbf{2}$ \\
\hline $\begin{array}{l}\text { Cruel, inhuman or degrading treatment or } \\
\text { punishment }\end{array}$ & & 3 & $\mathbf{1}$ \\
\hline Freedom of conscience & 32 & $15(1)$ & $\mathbf{1}$ \\
\hline Freedom of expression and speech & 27 & $16(2)$ & $\mathbf{2}$ \\
\hline Right to demonstrate & 27 & & $\mathbf{1}$ \\
\hline Freedom of peaceful assembly & 27 & 17 & $\mathbf{1}$ \\
\hline $\begin{array}{l}\text { Right to take part in the conduct of public } \\
\text { affairs }\end{array}$ & & $21(\mathrm{a})$ & $\mathbf{1}$ \\
\hline Freedom to travel & 31 & $8(2)$ & $\mathbf{3}$ \\
\hline Right to privacy of communication & 30 & 14 & $\mathbf{1}$ \\
\hline Right to have one's family protected & & $19(1)$ & $\mathbf{2}$ \\
\hline $\begin{array}{l}\text { Right to property and compensation for } \\
\text { deprivation of property }\end{array}$ & 105 & & $\mathbf{1}$ \\
\hline Right to final adjudication in the CFA & 82 & & $\mathbf{1}$ \\
\hline Right to confidential legal advice & 35 & & $\mathbf{1}$ \\
\hline Right to legal representation in the courts & 35 & & $\mathbf{1}$ \\
\hline Right of access to the courts & 35 & & $\mathbf{1}$ \\
\hline Freedom from arbitrary arrest & 28 & $5(1)$ & $\mathbf{1}$ \\
\hline $\begin{array}{l}\text { Arbitrary detention and imprisonment } \\
\text { (incl. review for legal certainty) }\end{array}$ & 28 & $5(1)$ & $\mathbf{5}$ \\
\hline Right to liberty and legal certainty of orders & 28,39 & $5(1)$ & $\mathbf{3}$ \\
\hline Non-retrospective crimes & & $12(1)$ & $\mathbf{1}$ \\
\hline Benefit of lighter penalty & 87 & $12(1)$ & $\mathbf{1}$ \\
\hline Right to a fair hearing & 87 & $11(1)$ & $\mathbf{3}$ \\
\hline Presumption of innocence & & \\
\hline
\end{tabular}




\begin{tabular}{|l|c|c|c|}
\hline \multicolumn{1}{|c|}{ Right or Freedom } & $\begin{array}{c}\text { Basic Law } \\
\text { Provision }\end{array}$ & $\begin{array}{c}\text { HKBOR } \\
\text { Provision }\end{array}$ & $\begin{array}{c}\text { Number of } \\
\text { Decisions }\end{array}$ \\
\hline $\begin{array}{l}\text { Right not to be compelled to testify against } \\
\text { oneself }\end{array}$ & & $11(2)(\mathrm{g})$ & $\mathbf{2}$ \\
\hline Right to examine witnesses & & $11(2)(\mathrm{e})$ & $\mathbf{1}$ \\
\hline $\begin{array}{l}\text { Right to have facilities for the preparation } \\
\text { of one's criminal defense }\end{array}$ & 87 & $11(2)(\mathrm{b})$ & $\mathbf{1}$ \\
\hline Right to trial without undue delay & & $11(2)(\mathrm{c})$ & $\mathbf{1}$ \\
\hline Right of appeal & & $11(4)$ & $\mathbf{1}$ \\
\hline Freedom from double jeopardy & & $11(6)$ & $\mathbf{1}$ \\
\hline Traditional rights of indigenous inhabitants & 40 & & $\mathbf{1}$ \\
\hline
\end{tabular}

The CFA has had the opportunity to consider a wide array of civil, political and legal rights. Most of these rights, however, have only been considered once by the Court and usually without extensive analysis. A developed body of jurisprudence has emerged for only a handful of rights, including the right of abode, presumption of innocence, legal certainty and arbitrary imprisonment, freedom to travel, and the freedom of expression and assembly.

Other than one case on the right to property, constitutional rights cases on economic, social and cultural rights are rare. The property rights case involved a corporate lease holder's right to compensation in government resumed land and thus was of little moment to the ordinary person. ${ }^{17}$ While the CFA has considered cases concerned with important economic and social issues, such as rent review and harbor reclamation, these cases have generally been decided on the basis of statutory construction or common law principles without invoking constitutional rights. ${ }^{18}$

\section{Who Are the Litigants in Constitutional Rights Cases?}

As evident in the areas of law data in Table 1, constitutional rights are most often invoked in the context of criminal prosecutions and judicial review proceedings (see Table 3 below). Few cases have arisen attacking law enforcement powers and pre-trial criminal proceedings/investigations, although non-constitutional rights cases in this context have been considered. ${ }^{19}$ Private litigants have managed to invoke constitutional rights but only in a handful of cases.

\section{Table 3: Procedural Origins of CFA Rights Cases}

\begin{tabular}{|l|c|}
\hline \multicolumn{1}{|c|}{ Type of Legal Proceedings } & Number of Cases \\
\hline Criminal prosecution and trial & 18 \\
\hline Pre-trial criminal proceedings & 2 \\
\hline Judicial review of executive acts and/or legislation & 16 \\
\hline
\end{tabular}

${ }_{17}$ See Dir. of Lands v. Yin Shuen Enterprises Ltd, 6 H.K.C.F.A.R. 1 (2003).

18 See, e.g., Town Planning Bd. v. Soc'y for the Protection of the Harbour Ltd, 7 H.K.C.F.A.R. 1 (2004); Ho Choi Wan v. Hong Kong Hous. Auth., 8 H.K.C.F.A.R. 628 (2005).

19 See, e.g., P v. Comm'r of Indep. Comm'n Against Corruption, 10 H.K.C.F.A.R. 293 (2007); Appeal Daily Ltd v. Comm'r of the Indep. Comm'n Against Corruption, 3 H.K.C.F.A.R. 26 (C.F.A. A.C.) (2000). 


\begin{tabular}{|l|c|}
\hline \multicolumn{1}{|c|}{ Type of Legal Proceedings } & Number of Cases \\
\hline Judicial review or appeal of administrative tribunal decision & 4 \\
\hline Lands Tribunal determination & 1 \\
\hline Litigation between private parties & 4 \\
\hline
\end{tabular}

Table 4 shows the backgrounds of the persons who have brought constitutional rights challenges. The group of challengers is diverse and no one particular group can be said to dominate the docket. While political activists, such as legislator Leung Kwok Hung, gain much public attention with each one of their politically inspired cases, activists were only behind about $9 \%$ of the CFA rights cases. Just under half of the cases involve legally aided challengers, reflecting the importance of public funding for accessing the court.

In one unusual case a government agency challenged the constitutionality of bankruptcy legislation (a "bankruptcy case" ${ }^{\prime 2}{ }^{20}$ It was a challenge to a provision that automatically extended a person's bankruptcy period whenever the bankrupt left Hong Kong without giving notice to the trustee. Given the practical problems of complying with this provision (particularly in identifying each occasion when a bankrupt had left and re-entered Hong Kong) the Official Receiver filed this challenge to the automatic extension rule. The two individual bankrupts, who stood to benefit if the constitutional challenge was successful, took no part in the proceedings. This case goes to show that even public authorities can often have an interest in ensuring that unconstitutional laws are struck down.

\section{Table 4: Persons Bringing Constitutional Challenges in CFA Cases}

\begin{tabular}{|l|c|}
\hline \multicolumn{1}{|c|}{ Background of Challengers } & Number of Cases \\
\hline Criminal defendants & 20 \\
\hline Prisoners & 1 \\
\hline Political activists & 4 \\
\hline Abode and residency claimants & 10 \\
\hline Rural villagers & 1 \\
\hline Corporate/director litigants & 9 \\
\hline Lawyer applicant/plaintiff & 2 \\
\hline Legal aid litigants & 22 \\
\hline Serving or former civil servant & 3 \\
\hline Government & 1 \\
\hline
\end{tabular}

None of the 45 cases raised any difficult standing issues before the CFA. Almost all cases concerned applicants who had some direct interest in the matter of the proceedings. ${ }^{21}$ It is inevitable that the Court will someday be asked to rule on

${ }^{20}$ See The Official Receiver and Tr. in Bankr. of Chan Wing Hing v. Chan Wing Hing, 9 H.K.C.F.A.R. 545 (2006).

${ }^{21}$ Leung Kwok Hung's standing to challenge the Executive Order on covert surveillance and the Chief Executive's statutory power to order interception of communication was considered in the Court of First Instance in Leung Kwok Hung \& Koo Sze Yiu v. Chief Exec. of the HKSAR, H.C.A.L. 107/2005, paras. 9-11 (C.F.I., Feb. 9, 2006), available at http://www.hklii.hk/hk/jud/ eng/hkcfi/2006/HCAL000107_2005-51499.html. 
whether persons without a direct interest in the matter can nevertheless bring the constitutional challenge on the basis of public interest standing. ${ }^{22}$ Such cases are controversial because they invariably raise questions to be answered in the abstract without a specific factual context. But where there are important constitutional law issues without affected persons willing and able to challenge the law, public interest standing may be the only way for the CFA to settle the issue. Hong Kong does not have any mechanism to allow legal questions of constitutional importance to be referred directly to the CFA for an opinion. ${ }^{23}$

The Hong Kong Government is the usual respondent in most of the rights cases (see Table 5 below). Lawyers in the Department of Justice (DOJ) will typically be responsible for instructing private counsel in these cases, and criminal appeals will sometimes involve in-house counsel in the Prosecutions Division of the DOJ (see below for further discussion). ${ }^{24}$

\section{Table 5: Respondents to Constitutional Challenges in CFA Cases}

\begin{tabular}{|l|c|c|}
\hline \multicolumn{1}{|c|}{ Respondents } & \multicolumn{2}{c|}{ Number of Cases } \\
\hline Government & \multicolumn{2}{|c|}{38} \\
\hline HKSAR & & 18 \\
\hline Secretary for Justice & & 1 \\
\hline Chief Executive of the HKSAR & & 1 \\
\hline Financial Secretary & & 9 \\
\hline Director of Immigration & & 1 \\
\hline Director of Lands & & 1 \\
\hline Commissioner of Police & & 1 \\
\hline Commissioner of Registration & & 1 \\
\hline Noise Control Authority & 2 & \\
\hline Stock Exchange of Hong Kong & 3 \\
\hline Law Society of Hong Kong & \multicolumn{2}{|c|}{} \\
\hline Private litigant & \multicolumn{2}{|c|}{} \\
\hline No respondent & & \\
\hline
\end{tabular}

\section{Legal Representation}

While legal representation is the norm in the CFA, there were eight cases $(18 \%)$ in which at least one party was unrepresented and four cases (8.9\%) in which one side of the dispute was unrepresented. The four cases involved two civil litigants and two criminal defendants. ${ }^{25}$ It is remarkable to see unrepresented

${ }_{22}$ For more on public interest litigation in Hong Kong, see Karen Kong, "Public Interest Litigation in Hong Kong: A New Hope for Social Transformation?", 28 Civ. Just. Q. 327 (2009); Po Jen Yap, "Understanding Public Interest Litigation in Hong Kong", 37 Common L. World Rev. 257 (2008).

${ }^{23}$ Compare with the reference mechanism in Canada's Supreme Court Act, R.S.C. 1985, C S-26, s. 53.

${ }^{24}$ Hong Kong still follows the English tradition of having a split legal profession consisting of barristers (known as counsel) and solicitors. Barristers receive instructions from solicitors to argue a particular case in the courts. For more information see Michael Wilkinson, Vandana Rajwani \& Raymond Pierce, Advocacy and the Litigation Process in Hong Kong 24-30 (3d ed. 2007).

25 See Ng Yat Chi v. Max Share Ltd \& Another, 8 H.K.C.F.A.R. 1 (2005) (concerning vexatious litigants); The Official Receiver and Tr. in Bankr. of Chan Wing Hing, 9 H.K.C.F.A.R. 545 (challenge by government to automatic rule extending period of bankruptcy); Lau Wai Wo v. HKSAR, 6 
litigants in the CFA for a substantive appeal; such a phenomenon rarely occurred in Hong Kong appeals to the PC.

Table 6 shows the proportion of cases with English and local silk (senior counsel) representing the different parties in a case. Almost a quarter of the cases $(24 \%)$ had English silk as leading counsel for at least one of the parties. ${ }^{26}$ The responding party (typically the government) tends to rely more on English silk than the parties bringing the constitutional challenge. One might question why with the development of its own common law legal system after 1997, Hong Kong still allows Queen's Counsel (QC) from England to parachute in to argue cases in the CFA. It must be remembered, however, that before 1997 almost all cases in the PC were argued on all sides by English counsel, although there might at times be Hong Kong junior counsel instructed as well. Hence the justification for having the ad hoc English QCs in local litigation is to continue the quality of advocacy in the final court and to ensure international influence in the jurisprudence, which is an important feature in the design of the new constitutional order.

Local senior counsel are also heavily involved in CFA rights litigation, being involved as leading counsel in almost $90 \%$ of the cases and as junior counsel in $36 \%$ of the cases. Where an amicus or intervener is involved, the counsel leading the party will usually be a local SC. Where an English QC is leading, there will typically be a local SC involved as well. However, it is not a requirement that leading counsel be either a QC or SC. About $18 \%$ of the cases had a junior barrister leading one of the parties, and this included amicus or intervener representation in two cases. This data on local representation is important as it shows that after 1997 final appeals were increasingly argued by local counsel who would be more familiar with local conditions. But this has also meant an increased variability in the quality of the representation appearing before the final court.

H.K.C.F.A.R. 624 (2003) (challenge to binding over order - amicus counsel appointed); David Morter v. HKSAR, 7 H.K.C.F.A.R. 53 (2004) (challenge to binding over order).

${ }^{26}$ English QCs admitted ad hoc include Iain Milligan, Lord Lester, Geoffrey Robertson, David Pannick, David Holgate, Clare Montgomery and Jonathan Caplan. QCs admitted locally who have appeared include Michael Thomas and Mark Strachan. 
Table 6: Legal Representation in the CFA Rights Cases

\begin{tabular}{|c|c|c|c|c|}
\hline $\begin{array}{c}\text { Leading and Junior } \\
\text { Counsel in the CFA }\end{array}$ & $\begin{array}{c}\text { Party } \\
\text { Invoking } \\
\text { Rights }\end{array}$ & $\begin{array}{c}\text { Responding } \\
\text { Party }\end{array}$ & $\begin{array}{c}\text { Amicus / } \\
\text { Intervener }\end{array}$ & $\begin{array}{c}\text { Overall } \\
\text { (No. of } \\
\text { Cases) }\end{array}$ \\
\hline \multicolumn{4}{|c|}{ Leading Counsel } \\
\hline $\begin{array}{c}\text { English QC } \\
\text { ad hoc admission) }\end{array}$ & $4 / 45=8.9 \%$ & $6 / 45=13.3 \%$ & 0 & $8 / 45=17.8 \%$ \\
\hline $\begin{array}{c}\text { English QC } \\
\text { (admitted locally) }\end{array}$ & $2 / 45=4.4 \%$ & $3 / 45=6.7 \%$ & 0 & $5 / 45=11.1 \%$ \\
\hline Local SC & $33 / 45=73.3 \%$ & $31 / 45=68.9 \%$ & $7 / 45=15.6 \%$ & $40 / 45=88.9 \%$ \\
\hline Junior Member & $3 / 45=6.7 \%$ & $5 / 45=11.1 \%$ & $2 / 45=4.4 \%$ & $8 / 45=17.8 \%$ \\
\hline Junior Counsel & $10 / 45=22.2 \%$ & 0 & $16 / 45=35.6 \%$ \\
\hline
\end{tabular}

In-house DOJ counsel tend to be more involved in criminal appeals than in civil appeals. The practice of the DOJ's Civil Division is to brief out their cases to private barristers while serving as instructing solicitors in each case. In the 22 criminal law related appeals, the DOJ's Prosecutions Division provided full in-house legal representation in $41 \%$ of the cases but had counsel involvement in $95 \%$ of those appeals.

Leading counsel representation in the rights cases has been concentrated in only a handful of senior barristers, thus demonstrating that human rights practice in Hong Kong is still very much a specialized area of practice. ${ }^{27}$ Several of the barristers representing parties invoking rights were also involved in politics as members of pro-democracy political parties. ${ }^{28}$

Of the barristers representing the responding party to the rights argument (typically the government party), five have been appointed permanently to the judiciary, ${ }^{29}$ whereas this has only happened to one of the barristers representing the party making the rights argument. ${ }^{30}$ However, one should not jump immediately to the conclusion that the Chief Executive of Hong Kong (who has the ultimate power to appoint judges) has attempted to appoint government-friendly lawyers who are more likely as judges to be biased in favor of the government party. In practice for a private barrister to be instructed by the government to represent its position in the CFA is itself an indication of the ability of that barrister. A long stream of government briefs engenders valuable litigation experience in the barrister. The appointment and promotion process is still very much controlled by the Chief Justice, Secretary for Justice

27 Some names of leading counsel who appear often in the rights cases include Michael Thomas SC, Denis Chang SC, Philip Dykes SC, Gerard McCoy SC, Gladys Li SC, Audrey Eu SC, Paul Harris SC, Clive Grossman SC and Kevin Zervos SC.

${ }^{28}$ Audrey Eu SC, Margaret Ng, and Gladys Li SC are core members of the Civic Party. Martin Lee $\mathrm{SC}$ is a member of the Democratic Party.

${ }^{29}$ Geoffrey Ma, who represented government in many of the right of abode cases, was the Chief Judge of the High Court and in September 2010 became the second Chief Justice of Hong Kong. Robert Tang was a Vice-President of the Court of Appeal and is currently Acting Chief Judge of the High Court. Daryl Saw, Jonathan Harris and Joseph Fok were more recently appointed judges of the Court of First Instance of the High Court.

${ }^{30}$ Michael Lunn, who was junior counsel in the first Lee Ming Tee case, is a judge of the Court of First Instance. 
(who is the minister of justice appointed by the Chief Executive) and senior members of the judiciary and legal profession. Thus judicial appointments and promotions in Hong Kong are merits driven and leave little room for political influence. As a Hong Kong judge enjoying security of tenure, comfortable remuneration, and independence under the Basic Law, there are unlikely to be any reasons for such a judge to want or need to be biased in favor of the government in his or her decision-making.

\section{E. Interveners and Amicus}

Human rights cases in the CFA have attracted very few additional parties as interveners or amicus curiae. Only three cases have involved an intervener, and no more than one intervener in each of those cases. The interveners have been public authorities or government parties, e.g., the Securities and Futures Commission and the Secretary for Justice. ${ }^{31}$ The practice of having public interest groups join proceedings as interveners has yet to take root in Hong Kong even though it is now commonplace in the final courts of the United Kingdom, Canada, the United States and many other places.

Only five cases had an amicus curiae. Of these only one amicus, the Equal Opportunities Commission, became such by application to the court, while the rest were appointed by the court or arranged through the Bar Association's Free Legal Service Scheme. ${ }^{32}$ Amicus counsel was appointed where a litigant was unrepresented and the assistance of counsel as a friend of the court was desirable (see Annex).

\section{F. Nature of the Constitutional Arguments}

Constitutional litigation can involve many procedural and substantive issues. A constitutional argument can also have many steps and levels of analysis. Table 7 shows how frequently different constitutional issues have been examined by the CFA. While procedural questions and issues concerning the scope of a right (i.e., the question of when a right is engaged) were relatively constant over the 10 years, more questions concerning justified restrictions on rights and remedial consequences of violations emerged in the latter half of the first decade. This reflects the increasing sophistication of rights argumentation in the CFA.

\section{Table 7: Constitutional Issues Examined by the CFA}

\begin{tabular}{|l|c|}
\hline Constitutional Issues Examined & Number of Cases and Time Period \\
\hline Procedural and jurisdictional issues & 11 \\
& $(1999-2002,2005-2008)$ \\
\hline
\end{tabular}

\footnotetext{
${ }^{31}$ The International Commission of Jurists was given leave to submit a written brief as an intervener in a recent Court of First Instance case, see W v. Registrar of Marriages, unreported, H.C.A.L. 120/2009, Oct. 5, 2010, Cheung J, paras. 259-263.

32 In Sec'y for Justice v. Chan Wah, 3 H.K.C.F.A.R. 293 (2000), Bokhary PJ (sitting alone) recognized the Court's jurisdiction to admit amicus curiae counsel by application of an interested body. But note the Court of Appeal's rejection of an amicus application made by a university legal research center. See C v. Dir. of Immigration, CACV 132/2008 (Aug. 17, 2009), available at http:/ / www.hklii. hk/hk/jud/eng/hkca/2009/CACV000132_2008-67155.html (last visited Mar. 18, 2011).
} 


\begin{tabular}{|l|c|}
\hline \multicolumn{1}{|c|}{ Constitutional Issues Examined } & Number of Cases and Time Period \\
\hline Delineation and engagement of rights & 33 \\
& $(1999-2008)$ \\
\hline $\begin{array}{l}\text { Justifiable restrictions on rights - } \\
\text { prescribed by law }\end{array}$ & $\begin{array}{c}7 \\
(2002-2005,2007)\end{array}$ \\
\hline $\begin{array}{l}\text { Justifiable restrictions on rights - } \\
\text { rationality and proportionality }\end{array}$ & 13 \\
\hline Constitutional remedies & $(1999-2001,2003,2005-2008)$ \\
\hline
\end{tabular}

In the right of abode cases the controversial procedural issue of Article 158 references to the NPCSC for interpretation of the Basic Law arose..$^{33}$ Other important procedural issues considered include the procedure to apply when appealing findings of unconstitutionality made by a magistrate ${ }^{34}$ and when a constitutional challenge will be allowed to be made for the first time on appeal. ${ }^{35}$

The Court's 2002 decision in HKSAR v. Shum Kwok Sher sparked a series of cases on the principle of legal certainty which has led to a rich jurisprudence of certainty review in respect of criminal offenses and executive powers. ${ }^{36}$

After the 2005 judgment in HKSAR v. Leung Kwok Hung, the Court paid closer attention to the issues of justifying restrictions on rights and appropriate remedies that should flow from a finding of unconstitutionality. ${ }^{37}$ Many of these cases have involved the government party playing a more sophisticated role in presenting constitutional arguments. Constitutional remedies are not only measures sought by the applicant party upon a successful rights violation being shown. Government now may seek a constitutional remedy (such as remedial interpretation) to save legislation from being declared unconstitutional or to suspend temporarily the declaration of unconstitutionality in order to allow the legislature time to pass corrective legislation. ${ }^{38}$

\footnotetext{
${ }^{33}$ Article 158 of the Basic Law provides that

if the courts of the Region, in adjudicating cases, need to interpret the provisions of this Law concerning affairs which are the responsibility of the Central People's Government, or concerning the relationship between the Central Authorities and the Region, and if such interpretation will affect the judgments on the cases, the courts of the Region shall, before making their final judgments which are not appealable, seek an interpretation of the relevant provisions from the Standing Committee of the National People's Congress through the Court of Final Appeal of the Region.

See also Interpreting Hong Kong's Basic Law: The Struggle for Coherence (Hualing Fu, Lison Harris, Simon NM Young eds., 2007) (particularly ch. 8).

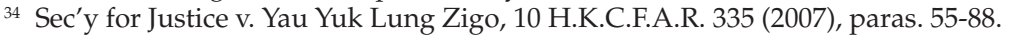

35 Noise Control Auth. \& Another v. Step In Ltd, 8 H.K.C.F.A.R. 113 (2005), para. 21.

36 See Shum Kwok Sher v. HKSAR, 5 H.K.C.F.A.R. 381 (2002) (applied in Lau Wai Wo v. HKSAR, 6 H.K.C.F.A.R. 624 (2003), David Morter, 7 H.K.C.F.A.R. 53, Noise Control Auth., 8 H.K.C.F.A.R. 113, Leung Kwok Hung v. HKSAR, 8 H.K.C.F.A.R. 229 (2005), and Mo Yuk Ping v. HKSAR, 10 H.K.C.F.A.R. 386 (2007)).

37 See Leung Kwok Hung, 8 H.K.C.F.A.R. 229.

38 The distinction between common law interpretation and constitutional remedial interpretation was articulated and applied in HKSAR v. Lam Kwong Wai, 9 H.K.C.F.A.R. 574 (2006) (concerning the presumption of innocence). Koo Sze Yiu v. Chief Exec., 9 H.K.C.F.A.R. 441 (2006) (recognizing the power of Hong Kong courts to suspend declarations of unconstitutionality for limited periods of time; considered by the UK Supreme Court in HM Treasury v. Ahmed [2010] UKSC 5). Another
} 


\section{G. Diversity of Judicial Opinions}

The composition of the CFA consists of a Chief Justice, three additional permanent judges (PJs), and a pool of non-permanent judges (NPJs), either from Hong Kong or from a common law jurisdiction. The appointed overseas NPJs have been eminent jurists from the United Kingdom, Australia and New Zealand. Appeals are heard in panels of five judges consisting of the permanent judges and no more than one overseas NPJ. Local NPJs preside when either the Chief Justice or another PJ is unavailable. In practice it is the Chief Justice who decides which NPJ(s) will sit to hear a particular appeal. The single panel consisting of Chief Justice Li, Chan PJ, Bokhary PJ, Ribeiro PJ and Sir Anthony Mason NPJ has heard the most rights cases together, totalling 19 cases or $42 \%$ of all rights cases. Assembling this "dream team" panel of judges to decide a large proportion of rights cases is a strategic decision to promote consistency in decision-making and a gradual evolution in rights jurisprudence.

Table 8 shows which of the PJs and NPJs have authored majority and minority opinions in rights cases and how often. Table 9 shows the tendency of the judges to accept the rights arguments in cases in which they have presided. The figures in Table 9 can be compared with the Court's overall rate of acceptance of rights arguments of $51 \%$.

Table 8: Judgment Writing in CFA Rights Cases

\begin{tabular}{|c|c|c|c|c|}
\hline & $\begin{array}{l}\text { Authorship/ } \\
\text { Co-Authorship } \\
\text { of Majority } \\
\text { Judgment }\end{array}$ & $\begin{array}{l}\text { Authorship } \\
\text { of Separate } \\
\text { Concurring } \\
\text { Judgment }\end{array}$ & $\begin{array}{c}\text { Authorship of } \\
\text { Dissenting } \\
\text { Judgment }\end{array}$ & Total \\
\hline \multicolumn{5}{|c|}{ Permanent Judges (PJs) } \\
\hline Li CJ & 17 & 2 & 0 & 19 \\
\hline Bokhary PJ & 10 & 13 & 5 & 28 \\
\hline Litton PJ & 0 & 1 & 0 & 1 \\
\hline Ching PJ & 0 & 1 & 0 & 1 \\
\hline Chan PJ & 7 & 0 & 0 & 7 \\
\hline Ribeiro PJ & 11 & 0 & 1 & 12 \\
\hline \multicolumn{5}{|c|}{ Non-permanent Judges (NPJs) (Overseas) } \\
\hline Mason NPJ & 12 & 2 & 0 & 14 \\
\hline Scott NPJ & 2 & 0 & 0 & 2 \\
\hline Brennan NPJ & 1 & 0 & 0 & 1 \\
\hline Millett NPJ & 1 & 0 & 0 & 1 \\
\hline Nicholls NPJ & 1 & 0 & 0 & 1 \\
\hline \multicolumn{5}{|c|}{ Non-permanent Judges (NPJs) (Local) } \\
\hline Power NPJ & 1 & 0 & 0 & 1 \\
\hline
\end{tabular}

important remedial case for government was Insider Dealing Tribunal v. Koon Wing Yee, 11 H.K.C.F.A.R. 170 (2008) where the Court was persuaded to strike out a non-infringing provision in order to minimize the impact of its finding that the Insider Dealing Tribunal conducted a criminal proceeding. 
Table 9: Tendency of PJs and Overseas NPJs to Accept Rights Argument

\begin{tabular}{|l|c|c|c|}
\hline & $\begin{array}{c}\text { \# of Rights } \\
\text { Appeals Heard }\end{array}$ & $\begin{array}{c}\text { Rights Argument } \\
\text { Accepted } \\
\text { \# of Appeals) }\end{array}$ & $\begin{array}{c}\text { Rate of } \\
\text { Acceptance of } \\
\text { Rights Argument } \\
\text { (\%) }\end{array}$ \\
\hline \multicolumn{3}{|l|}{ Permanent Judges (PJs) } \\
\hline Li CJ & 36 & 19 & 52.8 \\
\hline Bokhary PJ & 44 & 26 & 59.1 \\
\hline Litton PJ/NPJ & 7 & 3 & 42.9 \\
\hline Ching PJ & 6 & 3 & 50 \\
\hline Chan PJ & 37 & 18 & 48.6 \\
\hline Ribeiro PJ & 33 & 18 & 54.5 \\
\hline Non-permanent Judges (NPJs) (Overseas) & 18 & 58.1 \\
\hline Mason NPJ & 31 & 2 & 50 \\
\hline Scott NPJ & 4 & 0 & 0 \\
\hline Brennan NPJ & 1 & 1 & 33 \\
\hline Millett NPJ & 3 & 2 & 100 \\
\hline Nicholls NPJ & 2 & 0 & 0 \\
\hline Cooke NPJ & 2 & 0 & 0 \\
\hline Woolf NPJ & 2 & & \\
\hline
\end{tabular}

As seen in Tables 8 and 9, Chief Justice Li played a strong leadership role in achieving consensus and authoring judgments in the rights cases. He presided in $80 \%$ of the cases and authored judgments in $53 \%$ of those cases. Permanent judges, particularly the current three (Chan, Bokhary, Ribeiro PJJ) were also active in writing judgments, although not always forming part of the majority. By far, Sir Anthony Mason wrote the most rights judgments of all of the NPJs combined. He has written more majority judgments than any of the other PJs except Chief Justice Li. His influence on the jurisprudence is enormous, and his constant involvement has helped to ensure consistency in approach.

Only one of the local Hong Kong NPJs has written a majority or minority judgment, even though they were involved in a little more than a third (36\%) of the cases. ${ }^{39}$ This is a curious statistic as these judges would have written many of the HKBOR judgments both before and after 1997 during their service on the Court of Appeal. ${ }^{40}$

Dissent and separate opinions in the rights jurisprudence are a rarity. Only Justices Bokhary and Ribeiro have dissented. Justice Bokhary is well known for his dissent in human rights cases, particularly in the right of abode cases and in the freedom of assembly case, Leung Kwok Hung. He has the distinction of having sat on every rights case except one. ${ }^{41} \mathrm{He}$ is also the most prolific of

\footnotetext{
${ }^{39}$ Noel Power NPJ wrote the short majority decision in Chiu Wing Lam Dick v. HKSAR, 10 H.K.C.F.A.R. 613 (2007).

${ }^{40}$ On the work of local NPJs, see Simon NM Young, "The Hong Kong Multinational Judge in Criminal Appeals", 26 Law in Context 130 (2008).

${ }^{41}$ Bokhary PJ did not sit in Lau Cheong v. HKSAR, 5 H.K.C.F.A.R. 415 (2002), a case concerning a challenge to the mens rea and sentence for murder.
} 
all the judges, having written 28 majority and minority opinions (62\%) in all of the rights cases.

From studying the judgments it is possible at this juncture to discern three different conceptions of human rights amongst the CFA judges from 1999 to 2009. There is the mainstream view expounded primarily by Chief Justice Li and Sir Anthony Mason. It is a liberal yet pragmatic viewpoint that is close to the center of the political spectrum. Then there is Justice Bokhary's conception of human rights which draws a higher baseline of minimum rights protection than the mainstream view and shows particular concern for the interests of abode claimants and criminal defendants.

Justice Ribeiro's lone dissent in the bankruptcy case reveals a possible third conception of human rights in the Court. ${ }^{42}$ It is rare for Justice Ribeiro to depart from the mainstream view but in this case he had little sympathy for either of the delinquent bankrupts, who had their period of bankruptcy automatically extended each time they left Hong Kong without giving proper notice to the trustee, or the Official Receiver, who complained of practical difficulties in complying with the law. His conception would seem to emphasize duty and diligence as concomitant with the enjoyment of fundamental rights. It may, however, be premature to pigeonhole Justice Ribeiro into this third category for at least two reasons. First, he authored a very strong pro-rights judgment in March 2009 where he found the exclusion of lawyers from police disciplinary proceedings to violate the HKBOR. ${ }^{43}$ Second, his tendency to accept rights arguments shown in Table 9 is higher than that of other PJs.

Like the phenomenon of English counsel flying into Hong Kong to argue cases in the Court, the presence of overseas NPJ brings significant international influence to the Court's jurisprudence. All 45 cases had a sitting overseas NPJ who were former or sitting jurists of the Australian High Court, House of Lords or Privy Council. None of the New Zealand judges sat on any of the rights cases, a surprising absence as that jurisdiction has had a Bill of Rights Act since 1990. Sir Anthony sat on $67 \%$ of all cases. English jurists sat on $29 \%$ of all cases. ${ }^{44}$ The overseas judges authored (or co-authored) $38 \%$ of all the majority judgments in rights cases. Not one dissented, but this is true of the overseas judges in the CFA jurisprudence generally.

\section{H. Citation of Authorities}

The Basic Law expressly allows Hong Kong courts to make reference to "precedents of other common law jurisdictions" in adjudicating cases. ${ }^{45}$ As seen in Tables 10 and 11 CFA judgments have indeed made abundant references to both non-Hong Kong and non-United Kingdom (UK) authorities. The presence of the eminent overseas judge in every case and the occasional

\footnotetext{
${ }^{42}$ See The Official Receiver and Tr. in Bankr. of Chan Wing Hing, 9 H.K.C.F.A.R. 545.

43 See Lam Siu Po v. Comm'r of Police, 4 H.K.L.R.D. 575 [2009] (C.F.A.) (decided on March 26, 2009, falling just outside the 10-year mark for this study).

${ }_{44}$ Sir Robin Cooke NPJ is counted here as an English jurist although he originated from New Zealand.

${ }^{45}$ Basic Law, supra note 2, art. 84.
} 
presence of leading UK silk are factors that guarantee the continued relevance of comparative law to the development of the CFA's jurisprudence.

UK authorities (especially Human Rights Act 1998 jurisprudence) is still the dominant non-Hong Kong cited source. Canadian and United States constitutional cases are often considered, though not always followed. ${ }^{46}$ Probably the most influential source is the case law of the European Court of Human Rights, and members of the Court have expressly highlighted the importance of this case law on a few occasions. ${ }^{47}$ Academic writing is important to both majority and minority judgments although citation to such sources has not been excessive (see Table 12).

Table 10: Citation of Case Authorities in Majority, Concurring and Dissenting Judgments

\begin{tabular}{|c|c|c|c|c|}
\hline & $\begin{array}{c}\text { All } \\
\text { Judgments }\end{array}$ & $\begin{array}{c}\text { Majority } \\
\text { Judgments }\end{array}$ & $\begin{array}{c}\text { Concurring } \\
\text { Judgments }\end{array}$ & $\begin{array}{c}\text { Dissenting } \\
\text { Judgments }\end{array}$ \\
\hline Total Number of Citations & 1064 & 812 & 89 & 163 \\
\hline HK (CFA decisions) & & & & \\
\hline HK (non-CFA decisions) & $11 \%$ & $12 \%$ & $7 \%$ & $11 \%$ \\
\hline UK & $48 \%$ & $48 \%$ & $43 \%$ & $5 \% \%$ \\
\hline Non-HK \& UK Authorities & $27 \%$ & $24 \%$ & $38 \%$ & $28 \%$ \\
\hline Australia \& NZ & $7 \%$ & $7 \%$ & $6 \%$ & $4 \%$ \\
\hline Canada \& US & $9 \%$ & $8 \%$ & $20 \%$ & $9 \%$ \\
\hline Asia Pacific & $0.4 \%$ & $0.3 \%$ & $2 \%$ & $0 \%$ \\
\hline $\begin{array}{c}\text { Other National } \\
\text { Courts }\end{array}$ & $2 \%$ & $1 \%$ & $3 \%$ & $7 \%$ \\
\hline $\begin{array}{c}\text { International } \\
\text { Courts/Tribunals }\end{array}$ & $8 \%$ & $8 \%$ & $7 \%$ & $9 \%$ \\
\hline
\end{tabular}

Table 11: Citation of Legislative Authorities in Majority, Concurring and Dissenting Judgments

\begin{tabular}{|l|c|c|c|c|}
\hline & $\begin{array}{c}\text { All } \\
\text { Judgments }\end{array}$ & $\begin{array}{c}\text { Majority } \\
\text { Judgments }\end{array}$ & $\begin{array}{c}\text { Concurring } \\
\text { Judgments }\end{array}$ & $\begin{array}{c}\text { Dissenting } \\
\text { Judgments }\end{array}$ \\
\hline Total Number of Citations & 485 & 411 & 44 & 30 \\
\hline & & & & \\
\hline HK (Legislation, Basic Law) & $57 \%$ & $58 \%$ & $64 \%$ & $53 \%$ \\
\hline HK (Legislative materials) & $8 \%$ & $8 \%$ & $0 \%$ & $7 \%$ \\
\hline UK & $11 \%$ & $11 \%$ & $9 \%$ & $10 \%$ \\
\hline Non-HK \& UK Authorities & $23 \%$ & $23 \%$ & $27 \%$ & $30 \%$ \\
\hline
\end{tabular}

46 While the Canadian case law on delayed declarations of invalidity was influential in Koo Sze Yiu v. Chief Exec., 9 H.K.C.F.A.R. 441, Canadian Charter jurisprudence on the principle against self-incrimination has been less so. See HKSAR v. Lee Ming Tee, 4 H.K.C.F.A.R. 133 (2001). The CFA also did not follow the US Supreme Court's decision on flag desecration in United States v. Eichman, 496 U.S. 310 (1990).

47 See, e.g., Shum Kwok Sher v. HKSAR, 5 H.K.C.F.A.R. 381 (2002), paras. 59, 62-65; Chow Shun Yung, 6 H.K.C.F.A.R. 299, para. 36; Insider Dealing Tribunal v. Koon Wing Yee, 11 H.K.C.F.A.R. 170, para. 27; HKSAR v. Yeung May Wan, 8 H.K.C.F.A.R. 137 (2005), paras. 63-66; Lam Siu Po v. Comm'r of Police, 4 H.K.L.R.D. 575, para. 62. 


\begin{tabular}{|l|c|c|c|c|}
\hline & $\begin{array}{c}\text { All } \\
\text { Judgments }\end{array}$ & $\begin{array}{c}\text { Majority } \\
\text { Judgments }\end{array}$ & $\begin{array}{c}\text { Concurring } \\
\text { Judgments }\end{array}$ & $\begin{array}{c}\text { Dissenting } \\
\text { Judgments }\end{array}$ \\
\hline Australia \& NZ & $3 \%$ & $3 \%$ & $0 \%$ & $0 \%$ \\
\hline Canada \& US & $5 \%$ & $3 \%$ & $18 \%$ & $0 \%$ \\
\hline Asia Pacific & $2 \%$ & $2 \%$ & $2 \%$ & $0 \%$ \\
\hline $\begin{array}{l}\text { Other National } \\
\text { Legislation or } \\
\text { Constitutions }\end{array}$ & $2 \%$ & $1 \%$ & $5 \%$ & $7 \%$ \\
\hline $\begin{array}{l}\text { International } \\
\text { Treaties }\end{array}$ & $12 \%$ & $13 \%$ & $2 \%$ & $23 \%$ \\
\hline
\end{tabular}

Table 12: Citation of Academic Sources in Majority, Concurring and Dissenting Judgments

\begin{tabular}{|l|c|c|c|c|}
\hline & $\begin{array}{c}\text { All } \\
\text { Judgments }\end{array}$ & $\begin{array}{c}\text { Majority } \\
\text { Judgments }\end{array}$ & $\begin{array}{c}\text { Concurring } \\
\text { Judgments }\end{array}$ & $\begin{array}{c}\text { Dissenting } \\
\text { Judgments }\end{array}$ \\
\hline Total Number of Citations & 127 & 61 & 15 & 51 \\
\hline & & & & \\
\hline Books & $46 \%$ & $33 \%$ & $60 \%$ & $59 \%$ \\
\hline Articles & $31 \%$ & $26 \%$ & $33 \%$ & $37 \%$ \\
\hline $\begin{array}{l}\text { Practitioner Handbooks/ } \\
\text { Others }\end{array}$ & $22 \%$ & $41 \%$ & $7 \%$ & $4 \%$ \\
\hline
\end{tabular}

\section{Time to Hear}

Table 13 shows the average, minimum and maximum number of days the Court took to hear rights appeals in each year from 1999 to 2008.

Table 13: Days to Hear Appeals in CFA Rights Cases

\begin{tabular}{|l|c|c|c|}
\hline \multicolumn{1}{|c|}{ Year } & Average (days) & Max (days) & Min (days) \\
\hline 1997 & no rights cases & no rights cases & no rights cases \\
\hline 1998 & no rights cases & no rights cases & no rights cases \\
\hline 1999 & 2.5 & 5 & 1 \\
\hline 2000 & 4 & 4 & 4 \\
\hline 2001 & 3.2 & 6 & 1 \\
\hline 2002 & 4.6 & 10 & 2 \\
\hline 2003 & 3.6 & 11 & 1 \\
\hline 2004 & 1.5 & 2 & 1 \\
\hline 2005 & 2.8 & 4 & 1 \\
\hline 2006 & 2.3 & 5 & 1 \\
\hline 2007 & 2 & 3 & 1 \\
\hline 2008 & 1.3 & 2 & $\mathbf{1}$ (min) \\
\hline Overall & $\mathbf{2 . 8}$ (avg) & $\mathbf{1 1}$ (max) & 1 \\
\hline
\end{tabular}

On average the Court takes about three working days to hear a rights appeal. The most it has ever taken was 11 days when it heard the second Lee Ming Tee criminal appeal which involved the Securities and Futures Commission as 
intervener. Many appeals are heard within one day. In two cases, the Court heard and delivered an ex tempore judgment (i.e., one delivered from the bench) on the same day.

\section{J. Time to Render Judgment}

Table 14 shows the time the Court took to decide an argued rights appeal. The table counts the time to decide the case and not the time to deliver reasons for the decision.

Table 14: Time to Decide CFA Rights Appeals (with reasons to follow in some cases)

\begin{tabular}{|l|c|c|c|}
\hline \multicolumn{1}{|c|}{ Year } & Average (days) & Max (days) & Min (days) \\
\hline 1997 & no rights cases & no rights cases & no rights cases \\
\hline 1998 & no rights cases & no rights cases & no rights cases \\
\hline 1999 & 24 & 54 & 7 \\
\hline 2000 & 23 & 29 & 17 \\
\hline 2001 & 83 & 135 & 22 \\
\hline 2002 & 70 & 125 & 19 \\
\hline 2003 & 21 & 44 & 0 \\
\hline 2004 & 8.5 & 17 & 24 \\
\hline 2005 & 41 & 59 & 7 \\
\hline 2006 & 18.4 & 42 & 11 \\
\hline 2007 & 17 & 21 & 15 \\
\hline 2008 & 19 & 21 & $\mathbf{0}$ (min) \\
\hline Overall & $\mathbf{3 2 . 5}$ (avg) & $\mathbf{1 3 5}$ (max) & \\
\hline
\end{tabular}

On average, the Court takes just over a month to decide a rights appeal, and in most cases, the reasons will be given when the appeal is decided. This is quite an efficient standard that has the interests of litigants in mind. The year 2001 was the year of greatest delay with an average of almost three months to deliver judgment. That year saw a number of complex and difficult right of abode appeals together with (what appears to have been) a challenging disability discrimination case which took 133 days to decide. ${ }^{48}$

Later years show a decrease in the time needed to decide with performance figures in 2003, 2004, and 2006 to 2008 coming well below the overall average figure. The Court has been critical of lengthy delays in rendering judgment and by their own efficient standards they set an example for the rest of the judiciary to follow. ${ }^{49}$ A significant factor that has contributed to the efficient delivery of judgments has been the schedule of the visiting overseas NPJ. Efforts are made to ensure that appeals are decided and judgments prepared while the overseas judge is still in Hong Kong during his short visit, which is usually about four weeks in duration on each occasion.

\footnotetext{
48 See Ma Bik Yung v. Ko Chuen, 9 H.K.C.F.A.R. 888 (2006).

${ }^{49}$ For the criticisms of the Court of Appeal, see Yeung May Wan \& Others v. HKSAR, 8 H.K.C.F.A.R. 137 (2005), paras. 116-125.
} 
K. Length of Judgments

Table 15 details the average length of rights judgments in terms of word count.

Table 15: Judgment Word Counts in CFA Rights Cases (Average)

\begin{tabular}{|l|r|r|r|r|}
\hline \multicolumn{1}{|c|}{ Year } & Majority J & Sep Concur & \multicolumn{1}{c|}{ Dissent } & \multicolumn{1}{c|}{ Total } \\
\hline 1997 & no rights cases & no rights cases & no rights cases & no rights cases \\
\hline 1998 & no rights cases & no rights cases & no rights cases & no rights cases \\
\hline 1999 & $7,869(6)$ & $4,320(2)$ & $2,324(1)$ & $9,696(6)$ \\
\hline 2000 & $3,677(2)$ & $7,788(1)$ & $0(0)$ & $7,571(2)$ \\
\hline 2001 & $9,802(5)$ & $0(0)$ & $515(1)$ & $9,905(5)$ \\
\hline 2002 & $13,935(5)$ & $6,047(2)$ & $14,481(1)$ & $37,393(5)$ \\
\hline 2003 & $8,437(7)$ & $7,692(3)$ & $0(0)$ & $11,734(7)$ \\
\hline 2004 & $2,361(2)$ & $0(0)$ & $0(0)$ & $2,361(2)$ \\
\hline 2005 & $6,787(4)$ & $8,979(3)$ & $16,391(1)$ & $17,619(4)$ \\
\hline 2006 & $4,635(8)$ & $5,856(4)$ & $4,074(1)$ & $8,072(8)$ \\
\hline 2007 & $4,641(3)$ & $6,677(1)$ & $0(0)$ & $6,866(3)$ \\
\hline 2008 & $8,000(3)$ & $0(0)$ & $1,948(1)$ & $9,439(3)$ \\
\hline Overall & $\mathbf{7 , 2 3 5 ( 4 5 )}$ & $\mathbf{6 , 7 9 0 ( 1 6 )}$ & $\mathbf{6 , 9 5 6 ( 6 )}$ & $\mathbf{1 0 , 1 0 1 ( 4 5 )}$ \\
\hline
\end{tabular}

Almost as if the court was working on a fixed guideline, the average lengths of majority, separate concurring and dissenting opinions hover around 7,000 words. A 7,000 word judgment is equivalent to approximately 15 pages of judgment in the Hong Kong Court of Final Appeal Reports, the authorized law report of CFA judgments. This statistic can be misleading. For some cases there was a short majority judgment with lengthy separate concurring opinions (e.g., FACV11/2004: 203 words versus 7,031 words), whereas there were also cases with very long majority judgments and short separate opinions (e.g., FACC 4/2005: 11,573 words versus 116 words). The same applies to majority judgments that come with dissent (e.g., FACC20 and 21/2000: 5,066 words versus 515 words; FACC 1/2005: 10,483 words versus 16,391 words).

Overall, the average length of a full judgment (including all the minority opinions) is just over 10,000 words, a length that is almost twice that of the average PC judgment in the last decade of appeals. There is no obvious trend in judgment length - in order words, it cannot be said that judgments are getting longer in rights cases. The years 2002, 2003 and 2005 were lengthy judgment years, particularly due to long dissenting opinions from Justice Bokhary in 2002 and 2005. The overall increase in length of rights judgments (at least from the PC days) may simply reflect the worldwide expansion of human rights jurisprudence generally in the last decade, both from domestic courts and international tribunals. 


\section{IMPACT FOR LITIGANTS AND OTHERS}

\section{A. Government's Win/Loss Record}

Table 16 shows the government's tendency to win and lose in rights cases that reach the CFA. Of the 42 relevant cases, ${ }^{50}$ the government party tends to win the appeal in $55 \%$ of these cases. It tends to do a little better in criminal appeals than in non-criminal appeals. Counted amongst the winning cases is the unusual bankruptcy case in which the government party (the Official Receiver) was successful in challenging the legislation.

\section{Table 16: Win/Loss Record of Government in CFA Rights Cases}

\begin{tabular}{|l|c|c|c|}
\hline \multicolumn{1}{|c|}{ Case result } & Overall & FACC Cases & FACV Cases \\
\hline Government wins case & $\mathbf{2 3 ( 5 4 . 8 \% )}$ & $11(55 \%)$ & $12(54.5 \%)$ \\
\hline Government loses case & $\mathbf{1 9 ( 4 5 . 2 \% )}$ & $9(45 \%)$ & $10(45.5 \%)$ \\
\hline
\end{tabular}

The win/loss data, however, does not reflect the government party's tendency to win its constitutional argument. Although a party may win the appeal, it may have lost the constitutional issue in the judgment. An examination of how often the government parties win the contested constitutional issues, irrespective of the final result, reveals that they tend to lose more than they win (i.e., losing the main constitutional issue in $52 \%$ of the cases). ${ }^{51}$

With the increasing sophistication of constitutional argumentation in the Court, recent cases have made it difficult to say which party has won or lost the constitutional challenge in the Court. For example, in the two presumption of innocence cases in 2006, government had lost the violation and justification issues but had won the remedy issue in order to save the legislation from being declared invalid..$^{52}$ Also in 2006, both the government and applicant were in agreement that a temporary suspension (rather than a temporary validity) order was appropriate to allow law enforcement to continue with its covert surveillance and interception activities for a limited period of time while the legislature took corrective action. ${ }^{53}$

In the case of Koon Wing Yee, the government party failed in its attempt to have insider dealing proceedings treated as being non-criminal for purposes of Article 11 review under the HKBOR. ${ }^{54}$ However, it won on the remedial issue of having the penalty provision severed, thereby expunging the determining factor that had made the proceedings criminal in nature. This remedial consequence resulted in the quashing of the penalties actually ordered against the litigants but kept intact their findings of insider dealing and minimized the impact that could have resulted for other insider dealing cases.

\footnotetext{
50 The term "government" in this section is used broadly to include public authorities and professional bodies such as the Law Society of Hong Kong and Stock Exchange of Hong Kong.

51 There were four cases in which the government party had won the appeal but failed in their rights argument and one case in which the opposite occurred.

52 See HKSAR v. Lam Kwong Wai, 9 H.K.C.F.A.R. 574; HKSAR v. Hung Chan Wa, 9 H.K.C.F.A.R. 614 (2006).

53 See Koo Sze Yiu v. Chief Exec., 9 H.K.C.F.A.R. 441.

${ }^{54}$ See Insider Dealing Tribunal v. Koon Wing Yee, 11 H.K.C.F.A.R. 170.
} 


\section{B. Overturning the Court Below}

Table 17 shows the tendency of the Court to overturn or affirm the judgment in the court below (which is typically the Court of Appeal of the High Court). It is readily apparent that the Court has a stronger tendency to disagree with the court below, especially when it is prepared to accept the rights argument. This would suggest that the judges in the CFA are more willing to accept rights arguments than those in the courts below. The obvious inference is that the CFA has been more liberal in its rights decisions than that of the Court of Appeal. This raises concerns as to whether the new Chief Justice (who had presided on the Court of Appeal from 2002 to 2010) will attempt to restore the jurisprudential decisions or approaches of the Court of Appeal that had previously overturned or to continue in the liberal tradition of the CFA. ${ }^{55}$

Table 17: Overturning and Affirming the Court Below

\begin{tabular}{|c|c|c|}
\hline & \# of Cases & $\%$ of Cases \\
\hline All Rights Cases & 45 & 100 \\
\hline Court Below was Overturned & 24 & 53.3 \\
\hline Court Below was Affirmed & 21 & 46.7 \\
\hline $\begin{array}{l}\text { Where Rights Argument Was Accepted (Wholly or } \\
\text { Partially) }\end{array}$ & 23 & 100 \\
\hline Court Below was Overturned & 14 & 60.9 \\
\hline Court Below was Affirmed & 9 & 39.1 \\
\hline Where Rights Argument Was Rejected & 22 & 100 \\
\hline Court Below was Overturned & 10 & 45.5 \\
\hline Court Below was Affirmed & 12 & 54.5 \\
\hline
\end{tabular}

\section{How Are Constitutional Rights Used?}

Constitutional rights are used in a variety of ways and not always to challenge legislation or executive acts. As Table 18 shows, of the 45 cases, only 26 or $58 \%$ of the cases involved a direct challenge to law. In only 14 of these 26 cases did the court find an unjustified restriction on a fundamental right. Taking into account the possibility of remedial interpretation (which leaves the provision intact), the Court ordered declarations of unconstitutionality (i.e., severed words or provisions from legislation) in only nine cases ( $20 \%$ of all cases). ${ }^{56}$ Three of these cases concerned the right of abode. ${ }^{57}$ The other six cases involved challenges

\footnotetext{
55 For concerns expressed by Danny Gittings, see Danny Gittings, "Hong Kong's Courts are Learning to Live with China", H.K. J., July 2010, available at http:/ / www.hkjournal.org/PDF/2010_ fall/2.pdf (last visited Mar. 18, 2011).

${ }^{56}$ Koo Sze Yiu v. Chief Exec., 9 H.K.C.F.A.R. 441, is counted here, although strictly speaking the declarations of unconstitutionality made in the courts below were not in issue before the CFA. Only the issue of whether the unconstitutional legislation should have been made temporarily valid was before the CFA.

57 Declarations of unconstitutionality were made in respect of various words and provisions in the Immigration Ordinance (Cap. 115), Immigration (Amendment) (No 2) Ordinance, Immigration (Amendment) (No 3) Ordinance 1997, Immigration Regulations, and Gazetted Notice (G.No. (E.) 21 of 1997).
} 
to provision(s) in criminal or quasi-criminal laws (4 cases), bankruptcy laws, and laws governing the discipline of solicitors for misconduct. ${ }^{58}$

Table 18: Use of Constitutional Rights in the CFA Rights Cases

\begin{tabular}{|c|c|c|c|}
\hline $\begin{array}{c}\text { Use of Constitutional } \\
\text { Rights }\end{array}$ & $\begin{array}{l}\text { Number } \\
\text { of Cases }\end{array}$ & $\begin{array}{l}\text { Cases in Which } \\
\text { the Challenge } \\
\text { Succeeded } \\
\text { (partially or } \\
\text { wholly) }\end{array}$ & $\begin{array}{c}\text { Cases in Which } \\
\text { Declaration of } \\
\text { Unconstitutionality } \\
\text { Ordered }\end{array}$ \\
\hline $\begin{array}{l}\text { Challenge to the } \\
\text { validity of legislation } \\
\text { or common law }\end{array}$ & \begin{tabular}{|l}
\multicolumn{1}{c}{26} \\
Case \# 1-2, 4, 6, \\
10-12, 15-16, 19- \\
20, 23, 25, 31-32, \\
$34-38,40-45$ \\
\end{tabular} & \begin{tabular}{l}
\multicolumn{1}{c}{14} \\
Case\# 1-2, 11, 20, \\
25, 31, 34, 36-38, \\
$40-41,43-44$
\end{tabular} & \begin{tabular}{l}
\multicolumn{1}{c}{9} \\
Case\# 1-2, 20, 25, 31, \\
$34,36,41,44$
\end{tabular} \\
\hline $\begin{array}{l}\text { Challenge to a judicial } \\
\text { order or act without } \\
\text { challenging legislation }\end{array}$ & $\begin{array}{c}8 \\
\text { Case \# 3, 13, 18, } \\
21,24,26,28,39 \\
\end{array}$ & \begin{tabular}{l}
\multicolumn{1}{c}{4} \\
Case \# 3, 21, 24, \\
26
\end{tabular} & $\mathrm{n} / \mathrm{a}$ \\
\hline $\begin{array}{l}\text { Challenge to the acts } \\
\text { of a tribunal without } \\
\text { challenging legislation }\end{array}$ & $\begin{array}{r}1 \\
\text { Case \# } 33\end{array}$ & 0 & 0 \\
\hline $\begin{array}{l}\text { Challenge to executive } \\
\text { act without challenging } \\
\text { legislation }\end{array}$ & $\begin{array}{c} \\
\text { Case \# 5, 8-9, 14, } \\
17,22,27,29-30\end{array}$ & \begin{tabular}{l}
\multicolumn{1}{c}{5} \\
Case \# 8, 14, 17, \\
27,30
\end{tabular} & 0 \\
\hline $\begin{array}{l}\text { Development of the } \\
\text { common law }\end{array}$ & Case \# $7^{1}$ & $\mathrm{n} / \mathrm{a}$ & $\mathrm{n} / \mathrm{a}$ \\
\hline
\end{tabular}

In the notable case of Albert Cheng v. Tse Wai Chun Paul, which has received a measure of international attention, the Court invoked the freedom of expression to inform the development of the common law of defamation. ${ }^{59}$

\section{Types of Relief Ordered}

Table 19 shows the types of constitutional remedies and other relief that the Court has ordered where the challenge is found to be successful. Only in recent years (primarily in 2006 and thereafter) has the Court paid greater attention to constitutional remedies other than or in addition to declarations of unconstitutionality, such as remedial interpretation and temporary suspension. The Court has yet to consider the availability of further constitutional remedies such as damages and the exclusion of evidence. It has shown innovation and responsibility in one right of abode case ( $\mathrm{Ng}$ Siu Tung) in which it maintained

\footnotetext{
${ }_{58}$ Declarations or findings of unconstitutionality were made in respect of various words and provisions in the Legal Practitioners Ordinance (Cap. 159), Public Order Ordinance (Cap. 245), Telecommunications Ordinance (Cap. 106), Law Enforcement (Covert Surveillance Procedure) Executive Order, Bankruptcy Ordinance (Cap. 6), Crimes Ordinance (Cap. 200), and Securities (Insider Dealing) Ordinance (Cap. 395).

59 Albert Cheng v. Tse Wai Chun Paul, 3 H.K.C.F.A.R. 339 (2000), has been followed in Sugar v. Assoc. Newspapers Ltd [2002] QB 737, Panday v. Gordon [2005] UKPC 36, Channel Seven Adelaide Pty Ltd v. Manock [2007] HCA 60, WIC Radio v. Simpson [2008] 2 SCR 420, and other authorities.
} 
jurisdiction over the course of six years to ensure the proper disposition of thousands of related cases. ${ }^{60}$

The last column in Table 19 shows the cases in which the government party sought and obtained a constitutional remedy in order to achieve a more balanced result that gives effect to wider societal interests.

\section{Table 19: Types of Relief Ordered in CFA Rights Cases where the Constitutional Challenge was Successful}

\begin{tabular}{|c|c|c|c|}
\hline $\begin{array}{l}\text { Constitutional } \\
\text { Relief Ordered }\end{array}$ & $\begin{array}{l}\text { Number of } \\
\text { Cases }\end{array}$ & $\begin{array}{l}\text { Sought } \\
\text { by Private } \\
\text { Applicant }\end{array}$ & $\begin{array}{l}\text { Sought by } \\
\text { Government }\end{array}$ \\
\hline $\begin{array}{l}\text { Declaration of } \\
\text { unconstitutionality }\end{array}$ & $\begin{array}{c}9 \\
\text { Case\# 1-2, 20, 25, } \\
31,34,36,41,44\end{array}$ & \begin{tabular}{l}
\multicolumn{1}{c}{7} \\
Case\# 1-2, 20, 25, \\
$31,34,41$
\end{tabular} & $\begin{array}{c}2 \\
\text { Case\# 36, } 44\end{array}$ \\
\hline \begin{tabular}{|l|} 
Temporary suspension of \\
declaration
\end{tabular} & $\begin{array}{r}1 \\
\text { Case\# } 34 \\
\end{array}$ & Case\# $34^{1}$ & Case\# 34 \\
\hline $\begin{array}{l}\text { Remedial interpretation } \\
\text { Ef legislation }(e . g . \\
\text { reading down) }\end{array}$ & $\begin{array}{c}4 \\
\text { Case\# 17, 37-38, } 43\end{array}$ & Case\# $17^{1}$ & $\begin{array}{c}3 \\
\text { Case\# 37-38, } 43\end{array}$ \\
\hline \begin{tabular}{|l|} 
Other declaratory relief \\
\end{tabular} & \begin{tabular}{l}
\multicolumn{1}{c}{7} \\
Case\# 1, 2, 8, 11, \\
$14,20,34$
\end{tabular} & \begin{tabular}{|l}
\multicolumn{1}{|c|}{7} \\
Case\# 1, 2, 8, 11, \\
$14,20,34$
\end{tabular} & 0 \\
\hline $\begin{array}{l}\text { Quashing or setting aside } \\
\text { of order or decision }\end{array}$ & \begin{tabular}{l}
\multicolumn{1}{c}{12} \\
Case\# 1, 3, 14, \\
$20,24-27,30,38$, \\
40,42
\end{tabular} & \begin{tabular}{l}
\multicolumn{1}{c|}{12} \\
Case\# 1, 3, 14, \\
20, 24-27, 30, 38, \\
40,42
\end{tabular} & 0 \\
\hline \begin{tabular}{|l} 
Maintaining jurisdiction \\
\end{tabular} & Case\# $14^{1}$ & 0 & 0 \\
\hline
\end{tabular}

E. Impact of Jurisprudence beyond the Litigants

The CFA rights jurisprudence has had the most significant impact for right of abode and other immigration claimants. Beyond the right of abode and the freedom to travel, however, the wider societal impact of its jurisprudence has been modest in the first decade. Only two cases were associated with a direct legislative response. This was the village representative election case (Chan Wah) and the covert surveillance case (Koo Sze Yiu), which was only concerned with the issue of temporary validity when it reached the CFA. ${ }^{61}$

Criminal defendants have not benefited significantly from the Court's rights jurisprudence. The successful challenge to the homosexual buggery offense was itself the first prosecution for that offense since it was enacted in 1991 (Yau Yuk Lung). Small change (mostly in the form of police attitude and awareness)

\footnotetext{
${ }_{60}$ After the Court delivered judgment in Ng Siu Tung v. Dir. of Immigration, 5 H.K.C.F.A.R. 1, it remitted to the Court of First Instance (eventually handled by Hartmann J, as he then was) factual issues for determination in the outstanding claims. The judge of first instance made the determinations and submitted six reports to the Court for ultimate disposal. Based on the last report the Court disposed of the final batch of cases in a judgment delivered on March 18, 2008.

${ }_{61}$ The Village Representative Election Ordinance (Cap. 576) and Interception of Communications and Surveillance Ordinance (Cap. 589) were respectively the legislative impact of these two cases.
} 
would have resulted from the two political demonstration/assembly cases (Yeung May Wan and Leung Kwok Hung). The laws were very much left intact.

The insider dealing case (Koon Wing Yee) only generated a faint hope that previous insider dealers might have their paid penalties returned. ${ }^{62}$ The Court went out of its way to suggest that any challenges to the current market misconduct regime would likely be met with failure. ${ }^{63}$

Some impact has been seen in challenges to reverse burdens of proof in criminal matters, but even here the Court's willingness to embrace evidential burdens as a substitute for legal burdens leaves criminal laws intact and can result in little practical difference at trial. However, a fair number of defendants serving long sentences for drug trafficking have obtained new trials as a result of Hung Chan Wa which interpreted the presumption of knowledge provision as being rebuttable by discharge of an evidential burden. ${ }^{64}$

Perhaps the most meaningful impact that the Court's jurisprudence has had and will continue to have is in changing judicial and tribunal practices and behavior. Judges must now give reasons in refusing leave from arbitration appeals. ${ }^{65}$ Conditions in binding-over orders must be specified with sufficient detail and clarity, and the previous formulation of "keep the peace and be of good behavior" is no longer sufficient. ${ }^{66}$ No longer are appeals from disciplinary decisions immune from review by the CFA ${ }^{67}$ Offenders continue to receive the benefit of reduced sentencing tariffs even if reduced after the offense date. ${ }^{68}$ Forced apologies should not normally be ordered in disability discrimination cases. ${ }^{69}$ The impact of all these changes, however, is mostly limited to those proceedings in which these issues are likely to arise.

\section{CONCLUSIONS}

In his study of the first five years of HKBOR jurisprudence from 1991 to 1995 in all levels of court, Johannes Chan expressed disappointment with the low success rate (29\%) of rights arguments in the Court of Appeal which he believed had "adopted a conservative, sometimes even a contemptuous

\footnotetext{
${ }^{62}$ In light of recent cases, Tsang Yiu Kai \& Others v. Insider Dealing Tribunal [2008] 1 H.K.C. 376 (CA); Lau Luen Hung Thomas v. Insider Dealing Tribunal, unreported, FAMV 46/2009, December 4, 2009 (CFA AC), the hope has been extinguished for those whose time to appeal has expired.

63 The Court of First Instance (sitting with two judges) has upheld the constitutionality of the current Market Misconduct Tribunal. See Luk Ka Cheung v. Market Misconduct Tribunal [2009] 1 H.K.L.R.D. 114. The Court of Appeal also dismissed a second challenge to the former Insider Dealing Tribunal, see Koon Wing Yee v. Insider Dealing Tribunal, unreported, CACV 358/2005, June 8, 2009.

64 See, e.g., Chiu Wing Lam Dick, 10 H.K.C.F.A.R. 613; HKSAR v. Maria Cornelia Duvenhage, CACC 11/2009 (Apr. 29, 2009), available at http://www.hklii.hk/hk/jud/eng/hkca/2009/ CACC000011_2009-65579.html (last visited Mar. 18, 2011); HKSAR v. Muhammad Haji, CACC 125/2003 (June 25, 2007), available at http:/ / www.hklii.hk/hk/jud/eng/hkca/2007/

CACC000125_2003-57543.html (last visited Mar. 18, 2011).

65 See Swire Properties Ltd v. Sec'y for Justice, 6 H.K.C.F.A.R. 236 (2003).

${ }_{66}$ See Lau Wai Wo, 6 H.K.C.F.A.R. 624; David Morter, 7 H.K.C.F.A.R. 53.

67 See A Solicitor v. The Law Soc' of H.K., 6 H.K.C.F.A.R. 570 (2003).

68 See Mark Anthony Seabrook v. HKSAR, 2 H.K.C.F.A.R. 184 (1999).

69 See Ma Bik Yung, 9 H.K.C.F.A.R. 888.
} 
approach to Bill of Rights arguments" ${ }^{70}$ The overall success rate in all courts was $36 \% .{ }^{71} \mathrm{He}$ found that $74 \%$ of the HKBOR cases were criminal cases, many of which concerned presumption of innocence challenges to reverse onus provisions. ${ }^{72} \mathrm{He}$ also found that $75 \%$ of all HKBOR cases involved a challenge to the constitutionality of legislative provisions. ${ }^{73}$

As this study demonstrates, much has changed since the early HKBOR days. The introduction of additional rights provisions in the Basic Law has changed the rights landscape. But a more significant factor to change has been the unique institution of the CFA established under the Basic Law. No one would begin to suggest that any of the CFA judges has been contemptuous or even conservative towards rights. In contrast to the pre-1997 Court of Appeal (and to a lesser extent the post-1997 Court of Appeal), the CFA is a more liberal court that is institutionally designed to receive international influence. Rights cases in the immigration context have displaced the proportion of criminal rights cases. Rights arguments are now invoked by a wider range of litigants and for purposes other than to strike down legislation.

Specific conclusions that arise from this study are discussed under the following headings.

\section{A. Character of Rights Litigation in the CFA}

The Court has decided a fair number of constitutional rights cases in its first twelve years of operation..$^{74}$ The cases have allowed the Court to consider a range of fundamental civil, political and legal rights and to establish a developed body of jurisprudence for a handful of rights. The number of CFA rights cases far exceeds those heard in the Privy Council prior to 1997.

Litigants from different strata of society have managed to access the Court for final adjudication of their disputes. Corporate litigants have not dominated the docket, nor have criminal defendants. However, public interest litigation in the broad sense has not taken root in the CFA. Broad public interest standing has yet to be recognized, nor have public interest groups informed the Court's jurisprudence as amicus or intervener parties.

The Court has paid more attention to issues of justification and remedies in recent years. This reflects a greater sophistication by government and their counsel in handling constitutional argumentation. Constitutional cases have now become richer and more complex. With the increasing layers of issues in

${ }^{70}$ Johannes MM Chan, "The Hong Kong Bill of Rights 1991-1995: A Statistical Overview", in Hong Kong's Bill of Rights: Two Years Before 1997, at 7, 18-19 (George Edwards \& Johannes Chan eds., 1995).

${ }^{71}$ Id. at 18 .

${ }^{72} \mathrm{Id}$. at $8-9$.

${ }^{73} I d$. at 21.

${ }^{74}$ The Hong Kong figure of $17 \%$ is comparable to the proportion of Charter cases considered by the Supreme Court of Canada in the first decade of the Canadian Charter of Rights and Freedoms which was $18 \%$, but rises to $22 \%$ if the first two years of null Charter decisions are disregarded. See F.L. Morton, Peter H. Russell \& Troy Riddell, "The Canadian Charter of Rights and Freedoms: A Descriptive Analysis of the First Decade, 1982-1992", 5 Nat'l J. Const. L. 1, 3 (1995). 
constitutional cases it become more difficult to discern winning and losing parties after each appeal.

\section{B. International Influence}

International influence plays a significant role in shaping the jurisprudence of the Court. This influence can be said to be institutionalized in the presiding overseas NPJ in each case, the English counsel who appear before the courts, and the common practice of counsel and the judges to cite and consider overseas authorities. This international influence together with the contributions of the local senior bar contributes to the high quality of the judicial decisions thus far.

\section{Decision-Making: Consensus-Driven, Efficient and Consistent}

Decision-making in rights cases has been driven by consensus. The overseas NPJs, who never dissent, are instrumental in shaping or contributing to the majority viewpoint. The two judges who have had the most significant impact on the development of the rights jurisprudence have been Chief Justice Li and Sir Anthony Mason.

Although dissent is rare, there have been a sufficient number of alternative viewpoints expressed to reveal at least two different conceptions of rights protection amongst the current judges, and possibly a third one, as reflected in Justice Ribeiro's dissent in the bankruptcy case.

The Court has operated efficiently in hearing and deciding rights cases. The length of judgments has been reasonable, neither excessively long nor too curt to provide a satisfactory understanding of the reasoning. By assigning a core panel of judges to decide many of the rights cases, collective expertise and experience in the subject-matter has developed. This contributes to consistent decision-making and the potential for broad development of the jurisprudence.

D. Impact of the Jurisprudence

The Court has not allowed the constitutional instruments to become a 'rogue's Charter' by making decisions that widen the appeal opportunities of convicted criminal defendants. Many of the criminal justice challenges have failed. This does not necessarily suggest that the Court takes a stricter approach to criminal justice issues, but, rather, the points taken by counsel may not have been strong to begin with.

The impact of the rights jurisprudence has been mostly on the litigants before the Court and other litigants similarly situated. Only a small handful of cases have had more far-reaching implications. The Court struck down legislation in only nine cases (less than one per year), three of which were right of abode cases. Aside from the constitutional controversies concerning the right of abode in the early years, the Court's rights jurisprudence has generally been well received by members of the community and has not resulted in any major social unrest. 
Although the number of successful challenges have been relatively small, the Court's judgments (both majority and minority opinions) have played a very important normative role in stating (in a most public and authoritative manner) basic principles of human rights that lie at the heart of Hong Kong's separate system. In particular, the Court has made significant statements about the right of abode, equality and non-discrimination, the principle of legal certainty, freedoms of assembly, demonstration and expression, and the freedom to travel.

\section{E. The Future}

There is some uncertainty in the future direction of the Court and its rights jurisprudence. The two most influential rights judges in the first decade are unlikely to be as directly involved in the next decade. Chief Justice Li retired from the Court in August 2010 after a distinguished 13 years as the first chief of the final court. Sir Anthony Mason turned 85-years-old in 2010, although his current appointment runs to July 2012 and, until Sir Anthony signals his retirement from this court, there is the prospect of another extension.

On the other hand, there are a number of remaining factors that will contribute to the continuity of the Court's approach to rights. First, there is, of course, the jurisprudence itself that has a life of its own and a momentum that is unlikely to be impeded. Second, there are the aspects of institutionalized international influence that are likely to continue to contribute to the highest international standards in judicial decision-making. Third, judicial appointments in Hong Kong have not been politicized, and the Chief Justice has a substantial say in appointment decisions. ${ }^{75}$ These and other factors will help to guarantee the robust, liberal and mainstream approach to rights that the Court has applied in the first decade of rights jurisprudence.

\footnotetext{
${ }^{75}$ The Chief Justice is appointed by the "Chief Executive on the recommendation of an independent commission composed of local judges, persons from the legal profession and eminent persons from other sectors" (Article 88 of the Basic Law). The independent commission is known as the Judicial Officers Recommendation Commission and is chaired by the incumbent Chief Justice. See Judicial Officers Recommendation Commission Ordinance (Cap. 92), s. 3(1).
} 


\section{ANNEX}

First Ten Years of Rights Cases in the CFA (in chronological order by decision date)

\begin{tabular}{|c|c|c|c|c|c|c|}
\hline Case \# & Appellant & Respondent & Other Party & Citation & Case Number & $\begin{array}{c}\text { Date of } \\
\text { Decision }\end{array}$ \\
\hline 1 & $\begin{array}{l}\mathrm{Ng} \mathrm{Ka} \mathrm{Ling} \\
\text { \& Others }\end{array}$ & $\begin{array}{l}\text { Director of } \\
\text { Immigration }\end{array}$ & & $\begin{array}{l}(1999) 2 \\
\text { HKCFAR } 4\end{array}$ & $\begin{array}{l}\text { FACV14,15 } \\
\& 16 / 1998\end{array}$ & 29-Jan-99 \\
\hline 2 & $\begin{array}{l}\text { Chan Kam } \\
\text { Nga \& } \\
\text { Others }\end{array}$ & $\begin{array}{l}\text { Director of } \\
\text { Immigration }\end{array}$ & & $\begin{array}{l}(1999) 2 \\
\text { HKCFAR } 82\end{array}$ & FACV13/1998 & 29-Jan-99 \\
\hline 3 & $\begin{array}{l}\text { Mark } \\
\text { Anthony } \\
\text { Seabrook }\end{array}$ & HKSAR & & $\begin{array}{l}(1999) 2 \\
\text { HKCFAR } \\
184\end{array}$ & FACC6/1998 & 11-Mar-99 \\
\hline 4 & $\begin{array}{l}\text { Yung Kwan } \\
\text { Lee \& Others }\end{array}$ & $\begin{array}{l}\text { Secretary for } \\
\text { Justice }\end{array}$ & & \begin{tabular}{|l}
$(1999) 2$ \\
HKCFAR \\
245
\end{tabular} & FACV1/1999 & 4-Oct-99 \\
\hline 5 & $\begin{array}{l}\text { Director of } \\
\text { Immigration }\end{array}$ & $\begin{array}{l}\text { Lau Kong Yung } \\
\& \text { Others }\end{array}$ & & $\begin{array}{l}(1999) 2 \\
\text { HKCFAR } \\
300\end{array}$ & $\begin{array}{l}\text { FACV10\&11/ } \\
1999\end{array}$ & 3-Dec-99 \\
\hline 6 & HKSAR & $\begin{array}{l}\text { Ng Kung Siu \& } \\
\text { Another }\end{array}$ & & $\begin{array}{l}(1999) 2 \\
\text { HKCFAR } \\
442\end{array}$ & FACC $4 / 1999$ & 15-Dec-99 \\
\hline 7 & $\begin{array}{l}\text { Albert } \\
\text { Cheng \& } \\
\text { Another }\end{array}$ & $\begin{array}{l}\text { Tse Wai Chun } \\
\text { Paul }\end{array}$ & & $\begin{array}{l}(2000) 3 \\
\text { HKCFAR } \\
339\end{array}$ & FACV12/2000 & 13-Nov-00 \\
\hline 8 & $\begin{array}{l}\text { Secretary } \\
\text { for Justice \& } \\
\text { Others }\end{array}$ & $\begin{array}{l}\text { Chan Wah \& } \\
\text { Others }\end{array}$ & $\begin{array}{l}\text { Equal } \\
\text { Opportunities } \\
\text { Commission } \\
\text { (Amicus by } \\
\text { application) }\end{array}$ & $\begin{array}{l}(2000) \\
\text { HKCFAR } \\
459\end{array}$ & FACV11/2000 & 22-Dec-00 \\
\hline 9 & HKSAR & $\begin{array}{l}\text { Lee Ming Tee \& } \\
\text { Another }\end{array}$ & & \begin{tabular}{|l}
$(2001) 4$ \\
HKCFAR \\
133
\end{tabular} & FACC $8 / 2000$ & 22-Mar-01 \\
\hline 10 & $\begin{array}{l}\text { Tam Nga Yin } \\
\text { \& Others }\end{array}$ & $\begin{array}{l}\text { Director of } \\
\text { Immigration }\end{array}$ & & $\begin{array}{l}(2001) 4 \\
\text { HKCFAR } \\
251\end{array}$ & $\begin{array}{l}\text { FACV20\&21/ } \\
2000\end{array}$ & 20-Jul-01 \\
\hline 11 & \begin{tabular}{|l|} 
Director of \\
Immigration
\end{tabular} & $\begin{array}{l}\text { Chong Fung } \\
\text { Yuen }\end{array}$ & & \begin{tabular}{|l|}
$(2001) 4$ \\
HKCFAR 211
\end{tabular} & FACV26/2000 & 20-Jul-01 \\
\hline 12 & $\begin{array}{l}\text { Fateh } \\
\text { Muhammad }\end{array}$ & $\begin{array}{l}\text { Commissioner } \\
\text { of Registration }\end{array}$ & & $\begin{array}{l}(2001) 4 \\
\text { HKCFAR } \\
278\end{array}$ & FACV24/2000 & 20-Jul-01 \\
\hline 13 & Ma Bik Yung & Ko Chuen & & \begin{tabular}{|l|} 
(2006) 9 \\
HKCFAR \\
$888 ;[2002] 2$ \\
HKLRD 1 \\
\end{tabular} & FACV25/2000 & 5-Oct-01 \\
\hline 14 & $\begin{array}{l}\text { Ng Siu Tung } \\
\text { \& Others }\end{array}$ & $\begin{array}{l}\text { Director of } \\
\text { Immigration }\end{array}$ & & \begin{tabular}{|l}
$(2002) 5$ \\
HKCFAR 1
\end{tabular} & $\begin{array}{l}\text { FACV1,2\&3/ } \\
2001\end{array}$ & 10-Jan-02 \\
\hline 15 & $\begin{array}{l}\text { Shum Kwok } \\
\text { Sher }\end{array}$ & HKSAR & & $\begin{array}{l}(2002) 5 \\
\text { HKCFAR } \\
381\end{array}$ & FACC1/2002 & 10-Jul-02 \\
\hline 16 & $\begin{array}{l}\text { Lau Cheong } \\
\text { \& Another }\end{array}$ & HKSAR & & $\begin{array}{l}(2002) 5 \\
\text { HKCFAR } \\
415\end{array}$ & FACC6/2001 & 16-Jul-02 \\
\hline
\end{tabular}




\begin{tabular}{|c|c|c|c|c|c|c|}
\hline Case \# & Appellant & Respondent & Other Party & Citation & Case Number & $\begin{array}{c}\text { Date of } \\
\text { Decision }\end{array}$ \\
\hline 17 & $\begin{array}{l}\text { Director of } \\
\text { Immigration }\end{array}$ & $\begin{array}{l}\text { Gurung Kesh } \\
\text { Bahadur }\end{array}$ & & $\begin{array}{l}(2002) 5 \\
\text { HKCFAR } \\
480\end{array}$ & FACV17/2001 & 30-Jul-02 \\
\hline 18 & $\begin{array}{l}\text { Chau } \\
\text { Ching Kay, } \\
\text { Nauthum }\end{array}$ & HKSAR & & $\begin{array}{l}(2002) 5 \\
\text { HKCFAR } \\
540\end{array}$ & FACC $2 / 2002$ & 4-Dec-02 \\
\hline 19 & $\begin{array}{l}\text { Director of } \\
\text { Lands }\end{array}$ & \begin{tabular}{|l|} 
Yin Shuen \\
Enterprises Ltd
\end{tabular} & & $\begin{array}{l}(2003) 6 \\
\text { HKCFAR } 1\end{array}$ & FACV2\&3/2002 & 17-Jan-03 \\
\hline 20 & Prem Singh & $\begin{array}{l}\text { Director of } \\
\text { Immigration }\end{array}$ & & \begin{tabular}{|l} 
(2003) 6 \\
HKCFAR 26
\end{tabular} & FACV7/2002 & 11-Feb-03 \\
\hline 21 & \begin{tabular}{|l} 
Swire \\
Properties \\
Ltd \& Others
\end{tabular} & $\begin{array}{l}\text { Secretary for } \\
\text { Justice }\end{array}$ & & $\begin{array}{l}(2003) 6 \\
\text { HKCFAR } \\
236\end{array}$ & FACV13/2002 & 7-Jul-03 \\
\hline 22 & HKSAR & Lee Ming Tee & $\begin{array}{l}\text { Securities } \\
\text { and Futures } \\
\text { Commission } \\
\text { (Intervener) }\end{array}$ & $\begin{array}{l}(2003) 6 \\
\text { HKCFAR } \\
336\end{array}$ & FACC1/2003 & 22-Aug-03 \\
\hline 23 & $\begin{array}{l}\text { Tse Mui } \\
\text { Chun }\end{array}$ & HKSAR & & $\begin{array}{l}(2003) 6 \\
\text { HKCFAR } \\
601\end{array}$ & FACC4/2003 & 4-Dec-03 \\
\hline 24 & Lau Wai Wo & HKSAR & $\begin{array}{l}\text { Amicus - } \\
\text { from Bar } \\
\text { Association's } \\
\text { Free Legal } \\
\text { Service } \\
\text { Scheme }\end{array}$ & $\begin{array}{l}(2003) 6 \\
\text { HKCFAR } \\
624\end{array}$ & FACC5/2003 & 5-Dec-03 \\
\hline 25 & A Solicitor & $\begin{array}{l}\text { The Law } \\
\text { Society of Hong } \\
\text { Kong }\end{array}$ & $\begin{array}{l}\text { Secretary } \\
\text { for Justice } \\
\text { (Intervener) }\end{array}$ & $\begin{array}{l}(2003) 6 \\
\text { HKCFAR } \\
570\end{array}$ & FACV7/2003 & 19-Dec-03 \\
\hline 26 & $\begin{array}{l}\text { David } \\
\text { Morter }\end{array}$ & HKSAR & & $\begin{array}{l}\text { (2004) } 7 \\
\text { HKCFAR } 53\end{array}$ & FACC3/2004 & 10-Mar-04 \\
\hline 27 & $\begin{array}{l}\text { The } \\
\text { Director of } \\
\text { Immigration }\end{array}$ & Lau Fong & & $\begin{array}{l}(2004) 7 \\
\text { HKCFAR } 56\end{array}$ & FACV10/2003 & 26-Mar-04 \\
\hline 28 & $\mathrm{Ng}$ Yat Chi & $\begin{array}{l}\text { Max Share Ltd } \\
\text { \& Another }\end{array}$ & $\begin{array}{l}\text { Amicus } \\
\text { appointed by } \\
\text { the Court }\end{array}$ & \begin{tabular}{|l}
$(2005) 8$ \\
HKCFAR 1
\end{tabular} & FACV5/2004 & 20-Jan-05 \\
\hline 29 & \begin{tabular}{|l|} 
Noise \\
Control \\
Authority \& \\
Another \\
\end{tabular} & Step in Ltd & & $\begin{array}{l}(2005) 8 \\
\text { HKCFAR } 113\end{array}$ & FACV11/2004 & 4-Apr-05 \\
\hline 30 & $\begin{array}{l}\text { Yeung May } \\
\text { Wan \& } \\
\text { Others }\end{array}$ & HKSAR & & $\begin{array}{l}(2005) 8 \\
\text { HKCFAR } \\
137\end{array}$ & FACC19/2004 & 5-May-05 \\
\hline 31 & $\begin{array}{l}\text { Leung Kwok } \\
\text { Hung \& } \\
\text { Others }\end{array}$ & HKSAR & & $\begin{array}{l}(2005) 8 \\
\text { HKCFAR } \\
229\end{array}$ & $\begin{array}{l}\text { FACC1\&2/ } \\
2005\end{array}$ & 8-Jul-05 \\
\hline 32 & A Solicitor & $\begin{array}{l}\text { The Law } \\
\text { Society of Hong } \\
\text { Kong }\end{array}$ & & \begin{tabular}{|l}
$(2006) 9$ \\
HKCFAR \\
175
\end{tabular} & FACV23/2005 & 22-Mar-06 \\
\hline 33 & $\begin{array}{l}\text { The Stock } \\
\text { Exchange of } \\
\text { Hong Kong }\end{array}$ & $\begin{array}{l}\text { New World } \\
\text { Development } \\
\text { Co Ltd }\end{array}$ & & $\begin{array}{l}(2006) 9 \\
\text { HKCFAR } \\
234\end{array}$ & FACV22/2005 & 6-Apr-06 \\
\hline
\end{tabular}




\begin{tabular}{|c|c|c|c|c|c|c|}
\hline Case \# & Appellant & Respondent & Other Party & Citation & Case Number & $\begin{array}{c}\text { Date of } \\
\text { Decision }\end{array}$ \\
\hline 34 & $\begin{array}{l}\text { Koo Sze Yiu } \\
\text { \& Another }\end{array}$ & $\begin{array}{l}\text { Chief Executive } \\
\text { of the HKSAR }\end{array}$ & & $\begin{array}{l}(2006) 9 \\
\text { HKCFAR } \\
441\end{array}$ & $\begin{array}{l}\text { FACV12\&13/ } \\
2006\end{array}$ & 12-Jul-06 \\
\hline 35 & So Wai Lun & HKSAR & & $\begin{array}{l}(2006) 9 \\
\text { HKCFAR } \\
530\end{array}$ & FACC5/2005 & 18-Jul-06 \\
\hline 36 & $\begin{array}{l}\text { The Official } \\
\text { Receiver and } \\
\text { Trustee in } \\
\text { Bankruptcy } \\
\text { of Chan } \\
\text { Wing Hing } \\
\text { \& Another }\end{array}$ & $\begin{array}{l}\text { Chan Wing } \\
\text { Hing \& } \\
\text { Another }\end{array}$ & $\begin{array}{l}\text { Secretary } \\
\text { for Justice } \\
\text { (Intervener); } \\
\text { Amicus } \\
\text { appointed by } \\
\text { the Court }\end{array}$ & $\begin{array}{l}(2006) 9 \\
\text { HKCFAR } \\
545\end{array}$ & $\begin{array}{l}\text { FACV7\&8/ } \\
2006\end{array}$ & 20-Jul-06 \\
\hline 37 & HKSAR & $\begin{array}{l}\text { Lam Kwong } \\
\text { Wai \& Another }\end{array}$ & & $\begin{array}{l}(2006) 9 \\
\text { HKCFAR } \\
574\end{array}$ & FACC4/2005 & 31-Aug-06 \\
\hline 38 & HKSAR & $\begin{array}{l}\text { Hung Chan Wa } \\
\& \text { Another }\end{array}$ & $\begin{array}{l}\text { Amicus } \\
\text { appointed by } \\
\text { the Court }\end{array}$ & \begin{tabular}{|l}
$(2006) 9$ \\
HKCFAR \\
614 \\
\end{tabular} & FACC1/2006 & 31-Aug-06 \\
\hline 39 & $\begin{array}{l}\text { Yeung Chun } \\
\text { Pong \& } \\
\text { Others }\end{array}$ & $\begin{array}{l}\text { Secretary for } \\
\text { Justice }\end{array}$ & & $\begin{array}{l}(2006) 9 \\
\text { HKCFAR } \\
836\end{array}$ & FACC3/2006 & 13-Nov-06 \\
\hline 40 & $\begin{array}{l}\text { Chiu Wing } \\
\text { Lam Dick }\end{array}$ & HKSAR & & $\begin{array}{l}\text { (2007) } 10 \\
\text { HKCFAR } \\
613\end{array}$ & FACC10/2006 & 3-Jul-07 \\
\hline 41 & $\begin{array}{l}\text { Secretary for } \\
\text { Justice }\end{array}$ & $\begin{array}{l}\text { Yau Yuk Lung } \\
\text { Zigo \& Another }\end{array}$ & & $\begin{array}{l}(2007) 10 \\
\text { HKCFAR } \\
335\end{array}$ & FACC12/2006 & 17-Jul-07 \\
\hline 42 & Mo Yuk Ping & HKSAR & & $\begin{array}{l}(2007) 10 \\
\text { HKCFAR } \\
386\end{array}$ & FACC2/2007 & 25-Jul-07 \\
\hline \begin{tabular}{|l|}
43 \\
\end{tabular} & HKSAR & $\begin{array}{l}\text { Ng Po On \& } \\
\text { Others }\end{array}$ & & $\begin{array}{l}\text { (2008) } 11 \\
\text { HKCFAR } 91\end{array}$ & FACC6/2007 & 7-Mar-08 \\
\hline 44 & \begin{tabular}{|l} 
Insider \\
Dealing \\
Tribunal \& \\
Financial \\
Secretary
\end{tabular} & $\begin{array}{l}\text { Koon Wing Yee; } \\
\text { Chan Kin Shing } \\
\text { Sonny }\end{array}$ & & $\begin{array}{l}(2008) 11 \\
\text { HKCFAR } \\
170\end{array}$ & $\begin{array}{l}\text { FACV19\&20/ } \\
2007\end{array}$ & 18-Mar-08 \\
\hline 45 & $\begin{array}{l}\text { Yeung } \\
\text { Chung Ming }\end{array}$ & $\begin{array}{l}\text { Commissioner } \\
\text { of Police }\end{array}$ & & $\begin{array}{l}(2008) 11 \\
\text { HKCFAR } \\
513\end{array}$ & FACV22/2007 & 25-Jul-08 \\
\hline
\end{tabular}

